\title{
Projected Change-Atmosphere
}

\author{
Wilhelm May, Anette Ganske, Gregor C. Leckebusch, \\ Burkhardt Rockel, Birger Tinz and Uwe Ulbrich
}

\begin{abstract}
Several aspects describing the state of the atmosphere in the North Sea region are considered in this chapter. These include large-scale circulation, means and extremes in temperature and precipitation, cyclones and winds, and radiation and clouds. The climate projections reveal several pronounced future changes in the state of the atmosphere in the North Sea region, both in the free atmosphere and near the surface: amplification and an eastward shift in the pattern of NAO variability in autumn and winter; changes in the storm track with increased cyclone density over western Europe in winter and reduced cyclone density on the southern flank in summer; more frequent strong winds from westerly directions and less frequent strong winds from south-easterly directions; marked mean warming of $1.7-3.2{ }^{\circ} \mathrm{C}$ for different scenarios, with stronger warming in winter than in summer and a relatively strong warming over southern Norway; more intense extremes in daily maximum temperature and reduced extremes in daily minimum temperature, both in strength and frequency; an increase in mean precipitation during the cold season and a reduction during the warm season; a pronounced increase in the intensity of heavy daily precipitation events, particularly in winter; a considerable increase in the intensity of extreme hourly precipitation in summer; an increase (decrease) in cloud cover in the northern (southern) part of the North Sea region, resulting in a decrease (increase) in net solar radiation at the surface.
\end{abstract}

W. May $(\bowtie)$

Research and Development Department, Danish Meteorological Institute (DMI), Copenhagen, Denmark

e-mail:wm@dmi.dk

W. May

Centre for Environmental and Climate Research, Lund University, Lund, Sweden

e-mail: wilhelm.may@cec.lu.se

A. Ganske

Federal Maritime and Hydrographic Agency (BSH), Hamburg,

Germany

e-mail: Anette.Ganske@bsh.de

G.C. Leckebusch

School of Geography, Earth and Environmental Sciences,

University of Birmingham, Birmingham, UK

e-mail: G.C.Leckebusch@bham.ac.uk

\section{B. Rockel}

Institute of Coastal Research, Helmholtz-Zentrum Geesthacht, Geesthacht, Germany

e-mail: burkhardt.rockel@hzg.de

\section{B. Tinz}

German Meteorological Service (DWD), Hamburg, Germany e-mail: Birger.Tinz@dwd.de

U. Ulbrich

Institute of Meteorology, Freie Universität Berlin, Berlin, Germany

e-mail: ulbrich@met.fu-berlin.de 


\section{$5.1 \quad$ Introduction}

\section{Wilhelm May}

Projections of future climate change are obtained from simulations with global coupled as well as regional climate models (GCMs and RCMs, respectively). In these projections, concentrations or emissions of the well-mixed greenhouse gases and of the anthropogenic aerosol load are prescribed according to different scenarios, which take different possibilities for future developments into account. For the Fourth Assessment Report (AR4) of the Intergovernmental Panel on Climate Change (IPCC), these scenarios were based on the assumptions of the Special Report on Emission Scenarios (SRES; Nakićenović et al. 2000), while for the Fifth Assessment Report (AR5) the newly developed Representative Concentration Pathways (RCPs; Moss et al. 2010; van Vuuren et al. 2011) were applied. The RCP scenarios differ from the SRES scenarios in that they assume different pathways to specific targets of the radiative forcing by the end of the 21 st century. The two families of scenarios were also applied in the Coupled Model Intercomparison Project (CMIP), the SRES scenarios in phase 3 (CMIP3; Meehl et al. 2007a) and the RCP scenarios in phase 5 of the project (CMIP5; Taylor et al. 2012).

In the contributions of IPCC Working Group I to AR4, the projections of future climate change based on the SRES scenarios are presented in two different chapters, one addressing the global aspects of climate change (Meehl et al. 2007b) and one covering the regional aspects (Christensen et al. 2007). In the latter, the projected changes in climate are described separately for different continents and/or regions, including Europe. In 2012, the AR4 was complemented by the IPCC Special Report on climate extremes (SREX), where among others the observed and projected future changes in different kinds of extreme climate events were assessed (Seneviratne et al. 2012). In Table 3.3 of the latter report, the projected future changes in temperature and precipitation extremes were summarised for different regions, including northern, central and southern Europe. Also in 2012, the European Environment Agency (EEA) published a report on climate change, impacts and vulnerability in Europe, covering several aspects of climate and climate change (EEA 2012). In particular, the report includes references to several scientific publications based on future climate projections originating from a multi-model ensemble of RCM simulations for Europe performed within the ENSEMBLES project (Van der Linden and Mitchell 2009). The SRES scenarios were applied in these simulations. Recently, a new set of future climate projections for Europe has become available within the World Climate Research Programme (WCRP) Coordinated Regional Downscaling Experiment (CORDEX; Giorgi et al. 2009), with the aim to increase both the number of RCMs and the number of driving coupled climate models compared to the ENSEMBLES project. These scenario simulations are based on the RCP scenarios, with the driving coupled climate model data taken from CMIP5. As for Europe, a specific set of climate scenarios at a horizontal resolution of $12.5 \mathrm{~km}$ has become available within the CORDEX initiative, with seven different RCMs to date (Jacob et al. 2014). In ENSEMBLES, the finest horizontal resolution of the climate scenarios was $25 \mathrm{~km}$.

In the contributions of IPCC Working Group I to AR5, the global aspects of the projections of future climate change based on the RCP scenarios are presented in a specific chapter (Collins et al. 2013), while the regional aspects were covered differently to AR4. In AR5, future changes in the characteristics of a number of prominent climate phenomena, i.e., monsoon systems, the El Niño-Southern Oscillation, annular and dipolar modes and large-scale storm systems, and their relevance for regional climate change were assessed (Christensen et al. 2013a), with the regional changes in climate presented in the form of an atlas for as many as 18 different regions distributed over the globe (IPCC 2013). As for Europe, the northern and central parts of the continent and the Mediterranean region were distinguished. The regional aspects of the projections of future climate change were also considered in the contributions of Working Group II to AR5 (Hewitson et al. 2014a, b), again distinguishing between the aforementioned three parts of Europe. A detailed assessment of the impacts of the projected changes in climate for Europe, as for several other regions, is presented in a specific chapter of this part of AR5 (Kovats et al. 2014a, b).

Adaptation strategies are needed in response to the observed as well as to the projected changes in climate (Noble at el. 2014) and these are currently developed at the national and local level in many countries. This is typically done on the basis of national climate scenarios, which are already available for several countries and are likely to become more widespread in the future. Both the Netherlands (KNMI 2014) and Denmark (DMI 2014), for instance, have recently published reports on future climate scenarios for their countries. In Germany, future climate scenarios have even become available at a regional level through so-called regional climate offices, which cover different parts of the country. Despite their high value for the development of adaptation strategies for a particular country or part of a country, these national climate scenarios cannot easily be combined to give a consistent scenario for a larger area, such as the North Sea region. While the climate scenarios for Denmark follow closely the scenarios used in AR4 and AR5 (DMI 2014), the future climate scenarios for the Netherlands were developed by combining numerous climate scenarios originating from different climate models in accordance with the simulated rate of global warming and the simulated 
change in the large-scale circulation over western Europe (KNMI 2014). This distinction resulted in four categories of climate scenario: one with moderate warming (about $1.5^{\circ} \mathrm{C}$ by the end of the 21 st century) and a weak influence of circulation change (i.e. a small change in the frequency of the dominant circulation patterns relative to present-day conditions); one with moderate warming and a strong influence of circulation change (i.e. a large change in the frequency of the dominant circulation patterns); one with strong warming (about $3.5{ }^{\circ} \mathrm{C}$ by the end of the 21 st century) and a weak influence of circulation change; and one with strong warming and a strong influence of circulation change. The dominant circulation patterns are characterised by prevailing westerly winds during winter and prevailing easterly winds in association with high surface pressure during summer, respectively.

In this chapter, the projected changes in the atmosphere in the North Sea region are assessed on the basis of the existing literature, including the recent assessment reports referred to above. Typically, these changes have been projected for the end of the 21st century using conditions at the end of the 20th century as the baseline, but in the last few years several projections have also become available for the middle of the 21 st century. Because few studies have focussed specifically on the North Sea region, most of the results described here have been extracted from climate projections for Europe (based on RCM scenario simulations from ENSEMBLES or CORDEX) or even from projections covering the whole globe (based on GCM scenario simulations from CMIP3 or CMIP5). Several aspects describing the state of the atmosphere in the North Sea region have been considered, such as features of the large-scale circulation (Sect. 5.2), the mean and extremes, primarily at daily time scales, in temperature (Sect. 5.3) and precipitation (Sect. 5.4), cyclones and winds (Sect. 5.5), and radiation and clouds (Sect. 5.6).

\subsection{Large-Scale Circulation}

Uwe Ulbrich, Birger Tinz, Wilhelm May

\subsubsection{Prominent Climate Phenomena}

Regional climate is affected by various kinds of climate phenomena. Their change under rising greenhouse gas concentrations is thus relevant for future regional climate change (e.g. Christensen et al. 2013a). Prominent climate phenomena include the monsoon systems in different parts of the tropics, the El Niño-Southern Oscillation, different annual or dipolar modes, and blocking and large-scale storm systems. The interannual variability of the climate in the
North Atlantic region and specifically the North Sea region is mainly affected by two modes of variability: the North Atlantic Oscillation (NAO) and its hemispheric counterpart, the Northern Annular Mode (NAM) or Arctic Oscillation (e.g. Itoh 2008). Other large-scale factors affecting the climate in the Atlantic-European sector are atmospheric blocking and the strength and position of the Atlantic jet stream. These factors are all related to the strength and location of the Atlantic storm track and in turn to the NAO.

\subsubsection{Modes of Interannual Variability}

The NAO is a dipolar mode of climate variability, characterised by opposite variations in sea-level pressure between the Atlantic sub-tropical High and the Icelandic Low (e.g. Hurrell et al. 2003). Through its direct effect on westerly air flow into Europe, its link with Atlantic cyclones and atmospheric blocking, it strongly affects the climate over the North Atlantic Ocean and the surrounding continents (e.g. Hurrell and Deser 2009). The NAO can be established throughout the entire year, despite different physical mechanisms initiating and maintaining this mode of variability during winter and summer (e.g. Folland et al. 2009).

The CMIP5 simulations for the intermediate RCP4.5 scenario (i.e. 75 simulations with 37 different global climate models) show an overall amplification of the NAO up to the end of the 21 st century in all seasons, with the greatest increase in autumn (Gillett and Fyfe 2013). That is, the pressure difference between the Azores High and the Icelandic Low is projected to increase in these scenario simulations. This is consistent with earlier results from the CMIP3 simulations (Miller et al. 2006). These trends, however, are generally small compared to the natural climate variability (Deser et al. 2012). It should be noted that Gillett and Fyfe's (2013) use of a particular index to define the NAO might have had an effect on the magnitude of the projected change in the NAO, as the respective centres of action over the northern and southern parts of the North Atlantic might have different positions under a changing climate. For instance, Dong et al. (2011) found a poleward and eastward shift in the pattern of NAO variability in response to greenhouse gas forcing, in line with previous findings by Ulbrich and Christoph (1999). Both the future changes in the troposphere and the stratosphere as a direct response to the prescribed greenhouse gas forcing and the associated changes in sea surface temperatures in the North Atlantic contribute to the aforementioned changes in the NAO. In a recent study, Davini and Cagnazzo (2013) pointed at the possibility of misinterpreting the NAO signals in current climate models. This is because some of the models were not able to realistically simulate the physical processes connected to the NAO, namely atmospheric 
blocking and interaction with the Atlantic jet stream. This is particularly the case for those models that strongly underestimate the frequency of atmospheric blocking in the Greenland area. These shortcomings might affect studies analysing the NAO under different mean climate states, i.e. for future climate scenarios.

The NAO has been interpreted as the manifestation of an annular mode in sea-level pressure, the NAM, over the North Atlantic region (e.g. Thompson and Wallace 2000). Similar to their findings for the NAO, Gillett and Fyfe (2013) also found an overall amplification of the NAM under future climate conditions in all seasons. The increase is greatest in autumn and winter and smallest in summer. Furthermore, none of the climate models simulated a significant decrease in the NAM in any season.

\subsubsection{Atmospheric Blocking}

Atmospheric blocking is typically associated with persistent stationary or slowly moving high-pressure systems in the extratropics, interrupting the prevailing westerly winds and the usual track of eastward moving cyclones at these latitudes. Blocking occurs most frequently in the exit regions of the storm tracks in both hemispheres and is characterised by marked seasonal variability with high frequencies during winter and spring and low frequencies during summer and autumn (e.g. Wiedenmann et al. 2002; Masato et al. 2013). In the Atlantic-European sector blocking occurs more frequently over the North Atlantic in winter but more frequently over Europe in summer (e.g. Tyrlis and Hoskins 2008). Blocking is a major contributor to intraseasonal variability in the extratropics and can lead to seasonal climate anomalies over large parts of Europe (e.g. Trigo et al. 2004) as well as to climate extremes like cold spells in winter (e.g. Cattiaux et al. 2010) or heat waves in summer (e.g. Matsueda 2011). As previously mentioned, atmospheric blocking in the AtlanticEuropean sector during winter is strongly related to the NAO (Croci-Maspoli et al. 2007).

The CMIP5 simulations for the high RCP8.5 scenario show an overall decrease in the frequency of atmospheric blocking in the Atlantic-European sector in both winter (Cattiaux et al. 2013; Dunn-Sigouin and Son 2013; Masato et al. 2013) and summer (Dunn-Sigouin and Son 2013; Masato et al. 2013). The decrease in summer is accompanied by an increase on its eastern flank, leading to an eastward shift of the area with high blocking frequencies (Masato et al. 2013). While the decrease in winter is a consistent finding, regardless of how many different simulations from CMIP5 are considered or which method is used to define a blocking event, the situation is less clear in summer.
In contrast to the findings of Dunn-Sigouin and Son (2013) and Masato et al. (2013), Cattiaux et al. (2013) found an increase in the frequency of blocking events in the Atlantic-European sector during summer for most of the 19 CMIP5 models considered. The other two studies considered simulations from fewer CMIP5 models and used various indices to define blocking, while Cattiaux et al. (2013) used an approach based on weather regimes, with blocking being one of them. No noticeable changes, however, were found regarding the duration of individual blocking events (Dunn-Sigouin and Son 2013). These results are consistent with findings based on the CMIP3 simulations, which show a significant decrease in blocking frequency, particularly during winter (Barnes and Hartmann 2010; Barnes et al. 2012), but are somewhat less clear. According to Woollings (2010) the effect of greenhouse gas forcing on blocking might to a large extent reflect changes in the mean state of the atmosphere rather than dynamical processes directly associated with blocking. Barnes and Hartmann (2010) demonstrated, for instance, that a poleward shift in the Atlantic jet stream could lead to a decreased frequency of atmospheric blocking in winter due to a reduction in poleward Rossby-wave breaking.

\subsubsection{Sea-Level Pressure}

The AR5 reported an increase in mean sea-level pressure (MSLP) over western Europe and the adjacent part of the North Atlantic in winter, with a centre over the Mediterranean region, for $\mathrm{RCP} 2.6, \mathrm{RCP} 4.5$ and $\mathrm{RCP} 8.5$ (Collins et al. 2013). Further north the MSLP is markedly reduced. In summer, on the other hand, MSLP is reduced over Europe but increased over the North Atlantic, with a centre west of the British Isles. In both cases, the magnitude of the changes in MSLP follows the strength of the radiative forcing with the smallest (largest) changes in MSLP associated with the weakest (strongest) scenario. Van den Hurk et al. (2014) obtained similar results, when regressing changes in MSLP in the Atlantic-European region on the corresponding changes in global mean temperature for a total of 245 climate change simulations from CMIP5, covering 37 different global climate models, four scenarios (including RCP6.0) and ensemble simulations for some of the models. For spring and autumn, the authors found increases in MSLP over much of the North Atlantic and western Europe and decreases further north over the Arctic, but in contrast to winter, the maximum increases are centred over the North Atlantic during the transition seasons. The projected changes in MSLP contribute to the positive trend in the NAO and the NAM mentioned in Sect. 5.2.2, particularly in autumn. 


\subsubsection{Jet Stream}

The CMIP5 simulations show a small (about $1^{\circ}$ for the multi-model ensemble means) poleward shift in the position of the Atlantic jet stream for the RCP8.5 scenario, while its speed remains nearly constant (Barnes and Polvani 2013). The poleward shift in the position of the Atlantic jet steam was found to reduce its north-south wobble as well as to enhance the variability of its speed (i.e. more of a pulsing of the jet stream). Woollings and Blackburn (2012) obtained consistent results based on the CMIP3 simulations, both with regard to a poleward shift in the mean position of the Atlantic jet stream and to considerable variations between individual models, particularly in winter. The poleward shifts were often small compared to the errors in the simulation of the jet stream position. Moreover, Woollings and Blackburn (2012) found that the NAO in combination with the East Atlantic pattern (EA) of the large-scale circulation can describe both the climatological changes and the interannual variations of both the position and strength of the Atlantic jet stream at the tropopause level. It is largely the NAO that describes shifts in the position of the jet, whereas the NAO and EA are both associated with changes in the strength of the jet.

The mechanisms underlying a poleward shift in the jet stream are still not fully understood. Changes in the activity of large-scale planetary waves or in the characteristics of the synoptic-scale transient wave activity have been suggested to contribute to the poleward shift (e.g. Collins et al. 2013). Haarsma et al. (2013) found an eastward extension to the zonal winds at $500 \mathrm{hPa}$ over the eastern Atlantic Ocean and western Europe, primarily related to changes in the tropospheric temperature profile. The temperature changes in two regions were found to be important for forcing the changes in mean zonal flow: the relatively strong upper-tropospheric warming in the subtropics and the reduced surface warming in the mid-latitudes. Inter-model differences in the projected changes in mean zonal flow over the eastern Atlantic Ocean and western Europe could be partly attributed to uncertainties in the response of the North Atlantic Ocean to the anthropogenic forcing in both the CMIP3 and CMIP5 models.

\subsubsection{Summary}

Both the CMIP3 and CMIP5 simulations project marked future changes in various aspects of the large-scale circulation over the Atlantic-European region, of which the North Sea region is part. These changes are expected to affect the near-surface climate of the North Sea region, particularly in terms of weather and climate extremes. Examples include the impact of changes in the distribution of the phases of the
NAO on the occurrence of climate extremes in Europe (e.g. Scaife at el. 2008), and the role of atmospheric blocking over the North Atlantic on the occurrence of cold winter temperatures in Europe (Sillmann et al. 2011).

\subsection{Temperature}

Wilhelm May

\subsubsection{Global Mean Temperature}

The CMIP5 simulations project a global warming with respect to the present day (1986-2005) of between 1.0 (RCP2.6) and $2.0{ }^{\circ} \mathrm{C}$ (RCP8.5) by the mid-21st century and between $1.0(\mathrm{RCP} 2.6)$ and $3.7^{\circ} \mathrm{C}(\mathrm{RCP} 8.5)$ by the end of the 21 st century for the multi-model ensemble means (see Table 5.1). The projected changes in temperature vary considerably between models, with the uncertainty ranges depending on the magnitude of the projected multi-model changes. For the RCP2.6 scenario $90 \%$ of the projected changes by the middle of the 21 st century fall in the range 0.4-1.6 ${ }^{\circ} \mathrm{C}$ (the smallest mean change) and in the range 2.6$4.8{ }^{\circ} \mathrm{C}$ by the end of the 21 st century for RCP8.5 (the greatest mean change). Assuming a present-day (1986-2005) global warming of $0.61{ }^{\circ} \mathrm{C}$ with respect to the pre-industrial period (1850-1900; see Collins et al. 2013), means that under the RCP2.6 scenario global warming is most likely to stay below the internationally agreed target of limiting warming to less than $2{ }^{\circ} \mathrm{C}$ with respect to pre-industrial levels throughout the 21 st century, while it is most unlikely that global warming will stay below this threshold over the course of the $21 \mathrm{st}$ century under the RCP8.5 scenario.

\subsubsection{Regional Mean Temperatures}

According to Knutti and Sedláček (2012), the CMIP5 multi-model ensemble projects a so-called 'highly robust' mean surface warming in the North Sea region during both winter and summer. Part of this robust warming pattern is

Table 5.1 Projected change in annual global mean surface air temperature $\left({ }^{\circ} \mathrm{C}\right)$ by the mid- and end of the 21 st century relative to present day (1986-2005) for RCP2.6 (32 models), RCP4.5 (42 models) and RCP8.5 (39 models) obtained from the CMIP5 multi-model ensemble as well as the 5-95 \% ranges from the models' distribution

\begin{tabular}{l|l|l|l}
\hline Period & RCP2.6 & RCP4.5 & RCP8.5 \\
\hline $2046-2065$ & $1.0(0.4-1.6)$ & $1.4(0.9-2.0)$ & $2.0(1.4-2.6)$ \\
\hline $2081-2100$ & $1.0(0.3-1.7)$ & $1.8(1.1-2.6)$ & $3.7(2.6-4.8)$
\end{tabular}

Adapted from Collins et al. (2013, their Table 12.2) 
Table 5.2 Projected changes in mean surface air temperature $\left({ }^{\circ} \mathrm{C}\right)$ by the mid- and end of the 21 st century relative to present day $(1986-2005)$ for northern Europe (see Seneviratne et al. 2012, their Fig. 3.1) for RCP4.5 (42 models) and RCP8.5 (39 models) obtained from the CMIP5 simulations, in terms of winter (December through February; DJF), summer (June through August; JJA) and annual means

\begin{tabular}{l|l|l|l}
\hline Period & Season & RCP4.5 & RCP8.5 \\
\hline $2046-2065$ & DJF & $2.7(1.8-3.5)$ & $3.4(2.9-4.7)$ \\
\cline { 2 - 4 } & JJA & $1.8(1.2-2.5)$ & $2.5(1.9-3.2)$ \\
\cline { 2 - 4 } $2081-2100$ & ANN & $2.0(1.6-2.8)$ & $2.9(2.4-3.5)$ \\
\hline & DJF & $3.4(2.6-4.4)$ & $6.1(5.3-7.5)$ \\
\hline & JJA & $2.2(1.6-3.0)$ & $4.5(3.5-5.8)$ \\
\hline & ANN & $2.7(2.1-3.5)$ & $5.0(4.3-6.3)$
\end{tabular}

Data represent the median of the multi-model ensemble results and the 25th and 75th percentiles of the individual model responses. Adapted from Christensen et al. (2013a, their Table 14.1) and Christensen et al. (2013b, their Table 14.SM.1c), respectively

weaker warming over the North Sea than over the adjacent land areas, particularly in winter. This tendency is also evident in the climate change projections for northern and central Europe based on the CMIP5 multi-model ensemble presented in Annex I of AR5 (IPCC 2013). For the RCP4.5 scenario, the ensemble-mean future warming by the end of the 21 st century during winter is $1-2{ }^{\circ} \mathrm{C}$ over the North Sea and $3-4{ }^{\circ} \mathrm{C}$ over eastern Scandinavia. During summer, on the other hand, future warming is $2-3{ }^{\circ} \mathrm{C}$ for the entire northern and central European land areas compared to $1-2{ }^{\circ} \mathrm{C}$ over the North Sea. The regional patterns of future warming in the North Sea region are characterised by a west-east gradient with the strongest warming in the east during winter and a north-south gradient with the strongest warming in the south during summer. Averaged over northern Europe as a whole, the annual mean warming is between $2.0{ }^{\circ} \mathrm{C}$ (RCP4.5) and $3.4{ }^{\circ} \mathrm{C}$ (RCP8.5) by the middle of the $21 \mathrm{st}$ century and between $2.7{ }^{\circ} \mathrm{C}(\mathrm{RCP} 4.5)$ and $5.0^{\circ} \mathrm{C}(\mathrm{RCP} 8.5)$ by the end of the 21 st century (see Table 5.2). The strength of future warming over northern Europe varies between seasons with stronger warming during winter $\left(6.1^{\circ} \mathrm{C}\right)$ than during summer $\left(4.5^{\circ} \mathrm{C}\right)$, for RCP8.5 by the end of the $21 \mathrm{st}$ century (see Table 5.2).

The characteristic warming patterns over Europe are also revealed in a multi-model ensemble based on scenario simulations at high horizontal resolution $(\sim 12.5 \mathrm{~km})$ with 11 different RCMs for the RCP4.5 and RCP8.5 scenarios (Jacob et al. 2014). In summer (JJA), for instance, projected warming is $1.5-2{ }^{\circ} \mathrm{C}$ adjacent to the North Sea except for southern Norway, where the warming exceeds $2{ }^{\circ} \mathrm{C}$ (Fig. 5.1). In winter (DJF), on the other hand, warming is $1.5-2{ }^{\circ} \mathrm{C}$ in western Europe, $2-2.5{ }^{\circ} \mathrm{C}$ in central Europe and over $2.5^{\circ} \mathrm{C}$ in northern Europe. In spring (MAM), warming shows a very similar pattern to that for winter, but with slightly (by $\sim 0.5{ }^{\circ} \mathrm{C}$ ) weaker warming, while in autumn (SON) warming is $2-2.5{ }^{\circ} \mathrm{C}$ over the entire area adjacent to the North Sea. Averaged over the Atlantic region, which comprises the North Sea region except for southern Norway but including Ireland, France and the north-eastern part of the Iberian Peninsula (Metzger et al. 2005), the 11 climate scenarios give an annual mean warming of $1.7^{\circ} \mathrm{C}(\mathrm{RCP} 4.5)$ to $3.2{ }^{\circ} \mathrm{C}$ (RCP8.5) by the end of the 21 st century (see Table 5.3). These estimates of regional warming are somewhat lower than the corresponding estimates for northern Europe (see Table 5.2), which can be explained by northern Europe extending further north than the Atlantic region and not including south-western Europe.

The national climate scenarios also show marked future warming in the respective countries in response to anthropogenic forcing. For Denmark, the CMIP5 multi-model ensemble projects a future annual mean warming of 1.0 (RCP2.6), 1.8 (RCP4.5), and $3.7{ }^{\circ} \mathrm{C}(\mathrm{RCP} 8.5)$ by the end of the 21st century (DMI 2014). These estimates are about $30 \%$ lower than the corresponding estimates for northern Europe (see Table 5.2). For the Netherlands, the projected change in annual mean temperature by the end of the $21 \mathrm{st}$ century varies between $1.3{ }^{\circ} \mathrm{C}$ for the scenario with moderate warming and a weak influence of circulation change to $3.7{ }^{\circ} \mathrm{C}$ for the scenario with strong warming and a strong influence of circulation change (KNMI 2014). The projected annual mean temperature changes for the Netherlands by the mid-21st century are markedly weaker, at $1.0-2.3{ }^{\circ} \mathrm{C}$. Similarly, a multi-model ensemble of climate projections for Germany for the mid-21st century on the basis of seven combinations of RCMs and driving GCMs, gives a warming of $1.0-1.5^{\circ} \mathrm{C}$ for northern Germany under the SRES A1B scenario (Wagner et al. 2013).

\subsubsection{Temperature Extremes}

Changes in long-term averages for variables such as seasonal or annual mean temperature provide insight into relatively slow climatic change. However, in terms of impacts it is changes in the variability of temperature at much shorter time scales that are most relevant. For instance, weather and climate extremes at daily time scales or, in the case of extended warm spells and heat waves, at time scales of 


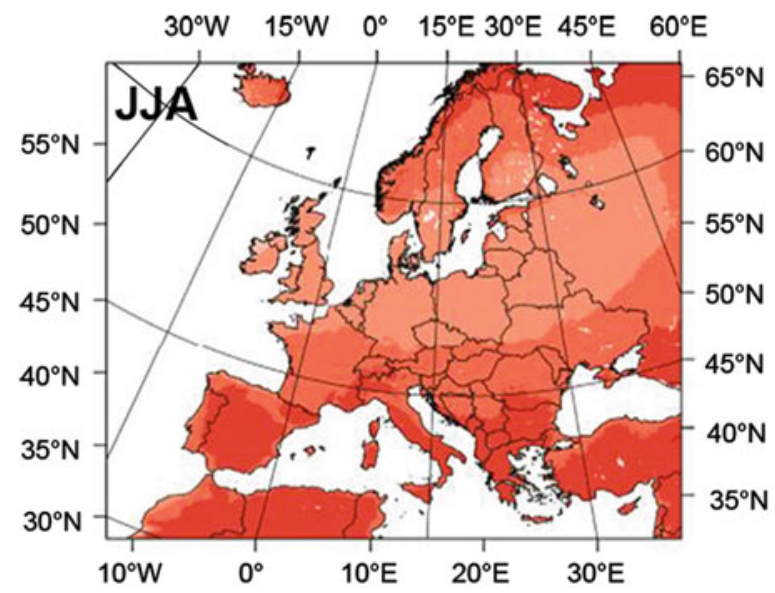

Changes are Significant
Changes are Robust

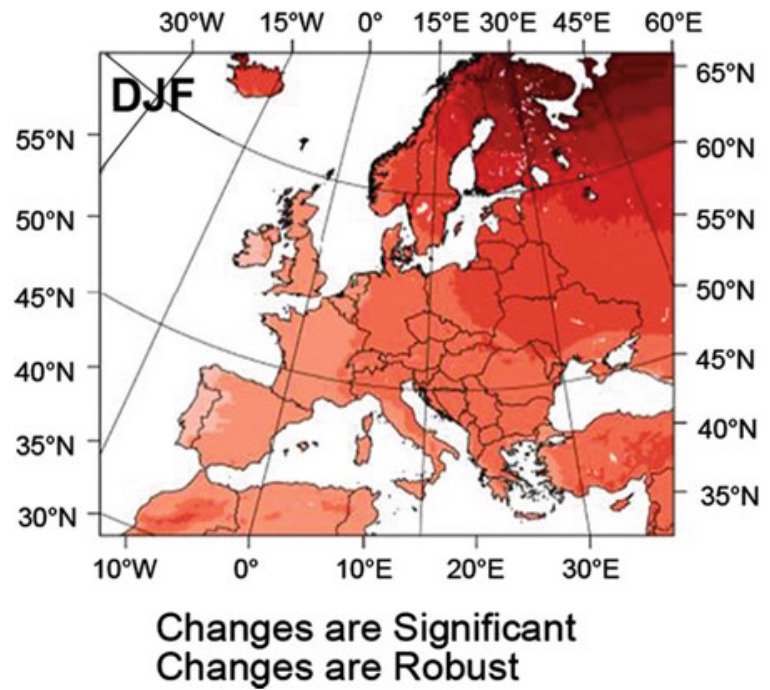

Fig. 5.1 Projected seasonal changes in surface air temperature (K) based on the RCP4.5 scenario for the end of the 21st century (2071-2100) relative to present day (1971-2000). All changes are both

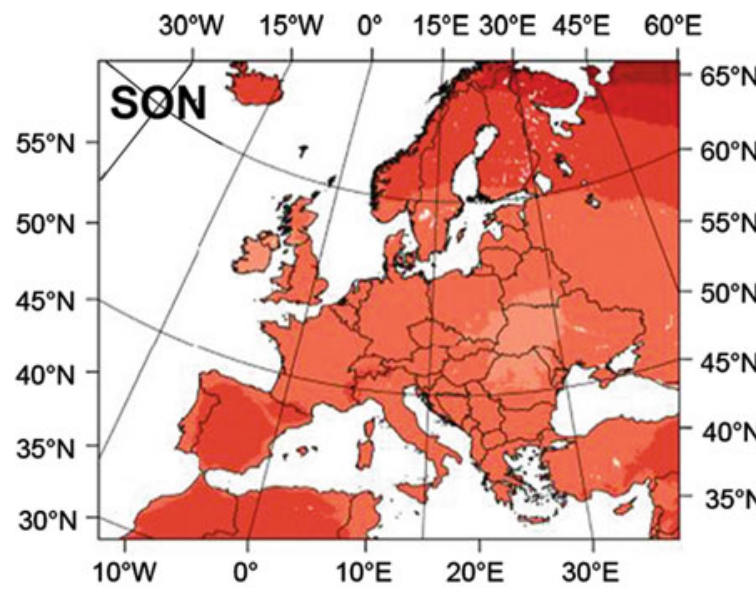

\section{Changes are Significant} Changes are Robust

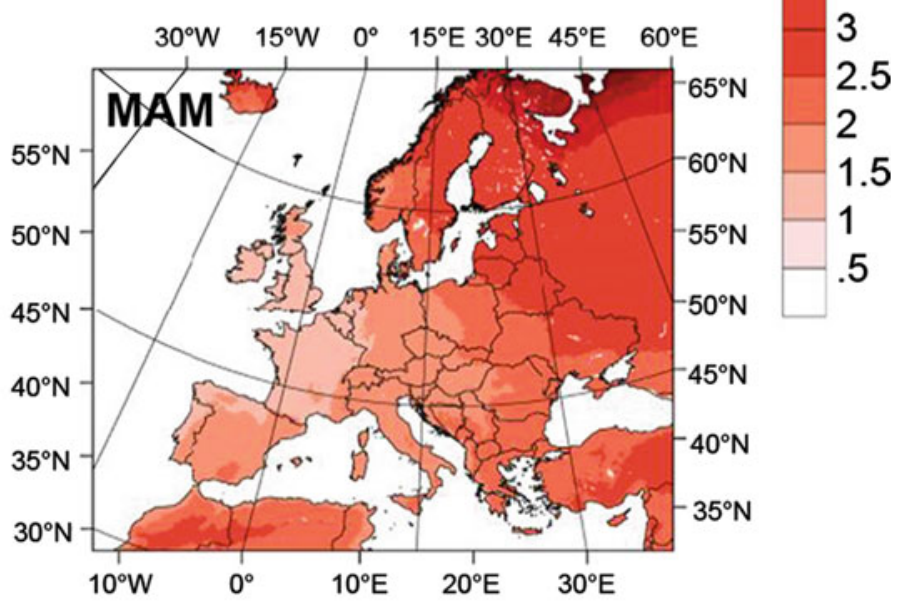

\section{Changes are Significant Changes are Robust}

robust and statistically significant. From the supplementary material of Jacob et al. (2014)

Table 5.3 Projected changes in selected temperature-related climate variables and indices by the end of the 21st century (2071-2100, with respect to 1971-2000) averaged over the Atlantic region (according to Metzger et al. 2005) for RCP4.5 (eight RCM simulations) and RCP8.5 (nine RCM simulations)

\begin{tabular}{l|l|l}
\hline Temperature-related climate indices & RCP4.5 & RCP8.5 \\
\hline Annual mean temperature $\left({ }^{\circ} \mathrm{C}\right)$ & $1.7(1.4$ to 2.1$)$ & $3.2(2.7$ to 3.6$)$ \\
\hline Frost days per year & $-28(-30$ to -15$)$ & $-40(-50$ to -26$)$ \\
\hline Summer days per year & $11(6$ to 14$)$ & $24(22$ to 28$)$ \\
\hline Tropical nights per year & $3(1$ to 5$)$ & $7(3$ to 12$)$ \\
\hline Growing season length (days per growing season) & $39(27$ to 43$)$ & $58(47$ to 68$)$ \\
\hline Warm spell duration index (days per year) & $21(19$ to 34$)$ & $67(47$ to 92$)$ \\
\hline Cold spell duration index (days per year) & $-4(-5$ to -4$)$ & $-5(-6$ to -4$)$
\end{tabular}

Data represent the median of the multi-model ensemble results and the likely range in these changes, defined to include $66 \%$ of all projected changes around the ensemble median. Adapted from Kovats et al. (2014b, their Table SM23-3) 
several days to weeks. A number of indices describing climate extremes have been developed based on some of the characteristics of the respective distributions of daily data. In a first attempt to coordinate and standardise the definition of such extremes, Frich et al. (2002) proposed five different indices concerning daily temperature data. Zhang et al. (2011) extended this list of extreme temperature indices to 15, also revising some of the definitions of Frich et al. (2002). In particular, these indices often focus on relative thresholds that describe the tails in the distribution rather than on specific physically-based thresholds. The indices of Zhang et al. (2011) capture both moderately extreme events that typically occur several times per year and extreme events that occur less often (once a year or less). In recognition of the strong impact of weather and climate extremes the IPCC published a special report on managing the risks of extreme events and disasters to advance climate change adaptation (SREX; IPCC 2012).

Kovats et al. (2014b) reported on projected changes in the characteristics of seven different temperature-related extremes based on the multi-model ensemble of highresolution RCM simulations for the RCP4.5 and RCP8.5 scenarios (Jacob et al. 2014). In Table 5.3 these changes are presented for the end of the 21st century averaged over the Atlantic region. The indices were defined in accordance with Zhang et al. (2011), that is, the number of frost days were defined as the annual count of days when the daily minimum temperature drops below $0{ }^{\circ} \mathrm{C}$, the number of summer days as the annual count of days when the daily maximum temperature exceeds $25^{\circ} \mathrm{C}$, the number of tropical nights as the annual count of days when the daily minimum temperature exceeds $20^{\circ} \mathrm{C}$, growing season length as the annual count between the first span of at least six days with daily mean temperatures above $5{ }^{\circ} \mathrm{C}$ and the first span after 1 July of six days with daily mean temperatures below $5{ }^{\circ} \mathrm{C}$, the warm spell duration index as the annual count of days with at least six consecutive days when the daily maximum temperature exceeds the respective 90th percentile, and the cold spell duration index as the annual count of days with at least six consecutive days when the daily minimum temperature drops below the respective 10th percentile.

The projected changes in these indices reveal the overall tendency of a future amplification of the extremes related to daily maximum temperature and a future reduction of the extremes related to daily minimum temperature. The number of summer days by the end of the 21 st century, for instance, is increased by 11 (24) for RCP4.5 (RCP8.5), while the number of frost days is reduced by 28 (40) (see Table 5.3). The changes are generally stronger for RCP8.5 than for RCP4.5, and for some indices the likelihood ranges based on individual models for the two scenarios do not show any overlap. This is the case for the number of summer days, growing season length and the warm spell duration index.
For the cold spell duration index, on the other hand, the likelihood ranges are similar for the two scenarios. The relatively large likelihood ranges for some indices indicate strong variation between the eight (RCP4.5) and nine (RCP8.5) projections with different RCMs that have been considered, and hence a high degree of uncertainty in the projected changes.

Kovats et al. (2014a) presented the geographical distributions of the projected change in the number of heat waves during May through September at the end of the 21st century on the basis of the same set of RCM simulations for the RCP4.5 and RCP8.5 scenarios. Heat waves were defined as periods of more than five consecutive days with daily maximum temperatures exceeding the mean daily maximum temperature for the reference period (1971-2000) by at least $5{ }^{\circ} \mathrm{C}$. For the North Sea region, the only area with notably more frequent heat waves was in southwestern Norway for RCP8.5, for RCP4.5 the number of heat waves does not change in that region. Jacob et al. (2014) defined heat waves differently, in this case as periods of more than three consecutive days with daily maximum temperatures exceeding the 99th percentile of the daily maximum temperature for the same reference period, and found markedly more heat waves over the North Sea region under RCP8.5 at the end of the 21 st century, with increases in the number of heat waves ranging from 10 to 15 for the Netherlands, northern Germany and Denmark, and exceeding 30 in southern Norway.

The CMIP5 simulations have also been used to assess the projected change in various temperature-related extremes in several studies, with some of these assessments being included in AR5 (Collins et al. 2013). Sillmann et al. (2013), for instance, presented global maps of the projected change in annual minimum and maximum temperatures (i.e. the minimum of the daily minimum temperatures and the maximum of the daily maximum temperatures occurring in the course of a year), in the number of frost days and in the number of tropical nights, in the number of cold nights (with daily minimum temperatures below the respective 10th percentile) and in the number of warm nights (with daily maximum temperatures exceeding the respective 90th percentile), as well as in the cold and warm spell duration indices at the end of the 21st century for the RCP2.6, RCP4.5 and RCP8.5 scenarios. Sillmann et al. (2013) also found notable future increases in both the annual minimum and maximum temperatures over western, central and northern Europe. Strong increases in annual minimum temperature of about $9-11{ }^{\circ} \mathrm{C}$ for RCP8.5 occur in northern Europe, presumably associated with retreating snow cover in this region. The strongest increases in annual maximum temperature, on the other hand, occur in central and eastern Europe, reaching about $6-8{ }^{\circ} \mathrm{C}$ for RCP8.5. Corresponding to these increases in annual temperature extremes, the number of frost days is markedly lower in central and 
northern Europe, while the number of tropical nights is much higher over southern Europe. In much of the North Sea region the number of tropical nights rises by about 10 days under RCP4.5 and by more than 20 days under RCP8.5, with tropical nights hardly ever occurring in this region under the present-day climate. Similarly, cold spells are projected to become shorter in the North Sea region, by about 3 days for RCP4.5 and about 4-6 days for RCP8.5. Warm spells are projected to become markedly longer in the North Sea region, by about 30 days for RCP4.5 and by 60120 days for RCP8.5. The national climate change assessment for the Netherlands also considers change in temperature-related extremes (KNMI 2014). In winter, for instance, the number of frost days is projected to decrease by 35-80\% (with respect to 38 days for the reference period 1981-2000) at the end of the 21st century, with the weakest change for the scenario with moderate warming and weak influence of circulation change and the strongest change for the scenario with strong warming and strong influence of circulation change. For the scenarios with strong warming, the differences between a weak and strong influence of circulation change account for $20 \%$ of the projected fall in the number of frost days. The number of summer days, on the other hand, is projected to increase by $30-130 \%$ (relative to 21 days for the reference period 1981-2000), again depending on the overall strength of the scenario.

Kharin et al. (2013) used 20-year return levels to assess future changes in annual extremes of daily temperature at the end of the 21st century for the RCP2.6, RCP4.5 and RCP8.5 scenarios on the basis of the CMIP5 simulations for the entire globe. In the North Sea region, the multi-model ensemble projects increases in the 20-year return levels of the annual minimum temperatures of $4-8{ }^{\circ} \mathrm{C}$ for RCP4.5 and $8-12{ }^{\circ} \mathrm{C}$ for RCP8.5. The projected increases in the 20 -year return levels for annual maximum temperature in the North Sea region are somewhat weaker, at $2-4{ }^{\circ} \mathrm{C}$ for RCP4.5 and $6-8{ }^{\circ} \mathrm{C}$ for RCP8.5. Nikulin et al. (2011) used 20-year return levels to assess future change in annual extremes of daily temperature in Europe at the end of the 21st century on the basis of an ensemble of six scenario simulations with one particular RCM forced by six different GCMs applying the SRES A1B scenario (Fig. 5.2). According to these scenario simulations, the 20-year return levels for annual minimum temperature increase by about $4-10{ }^{\circ} \mathrm{C}$ over most of the North Sea region, while the respective return levels for the annual maximum temperature increase only by about $2-4^{\circ}$ C. Nevertheless, waiting times for a 20-year event of the annual maximum temperature during the reference period (1961-1990) are reduced to 2-5 years in the North Sea region, meaning that at the end of the 21 st century such an event is expected to occur every two to five years.

Schoetter et al. (2014) assessed changes in the characteristics of western European heat waves projected in the CMIP5 ensemble at the end of the 21 st century. In this case heat waves were defined as periods of three consecutive days, during which at least $30 \%$ of western Europe is affected by extremely high temperatures (exceeding the 98th percentile of the daily maximum temperatures for the period May through October). The study covers the UK, Belgium, the Netherlands and northern Germany as parts of the North Sea region. Heat waves in western Europe become more frequent and of greater duration, increase in extent and
Fig. 5.2 Left-hand panels The ensemble mean of (upper panel) the 20-year return level of daily maximum temperature $\left(\mathrm{T}_{\max , 20}\right)$ and (lower panel) the 20-year return level of daily minimum temperature $\left(\mathrm{T}_{\min , 20}\right)$ for 19611990 and (middle panel) the respective changes of $\mathrm{T}_{\max , 20}$ and $\mathrm{T}_{\min , 20}$ in 2071-2100 relative to 1961-1990 ( $\left.{ }^{\circ} \mathrm{C}\right)$. Only differences significant at the $10 \%$ significance level are shown. Right-hand Panel Waiting times (years) of the 1961-1990 $\mathrm{T}_{\max , 20}$ in 2071-2100 (Nikulin et al. 2011)
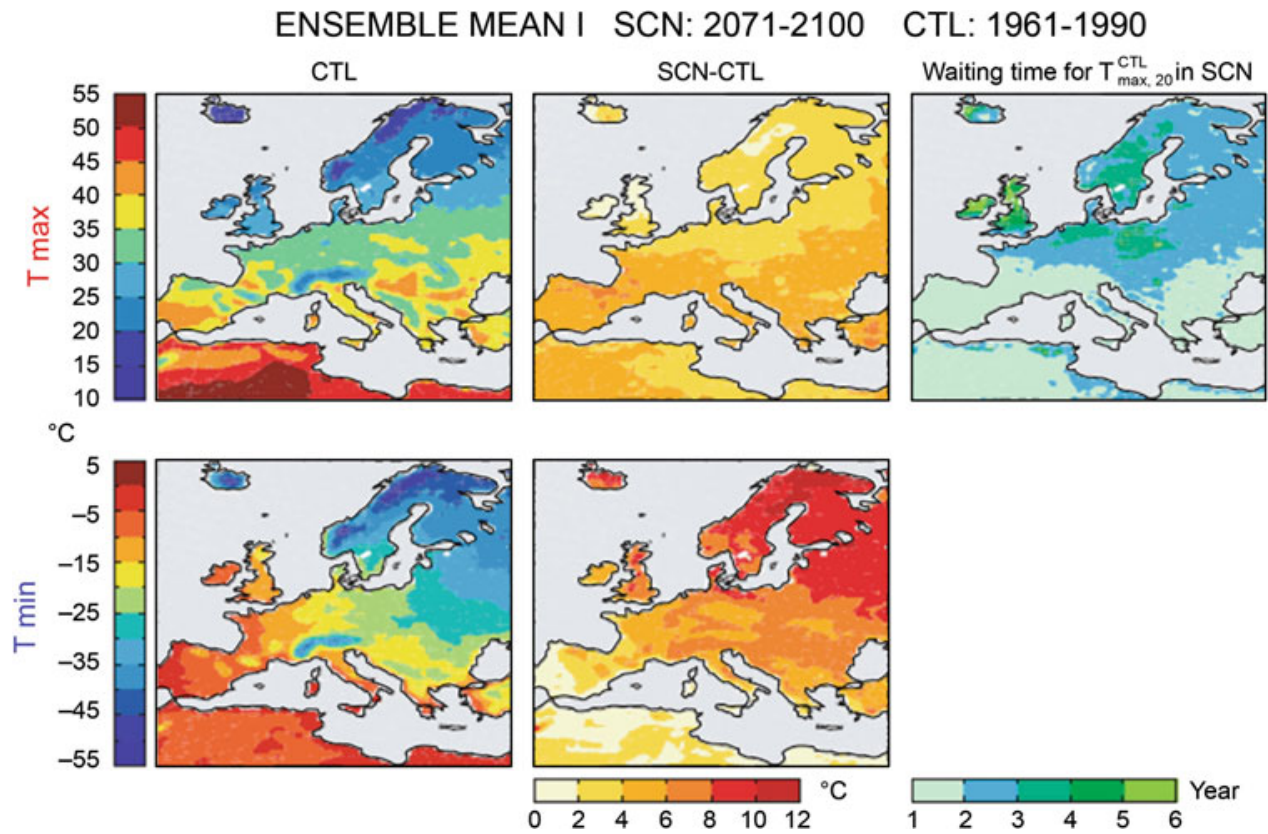
become more intense. Heat waves that are similar to or stronger than the one observed across Europe in 2003 remain rare under RCP2.6 and RCP4.5, but become the norm under RCP8.5. For the latter, heat waves with five times the severity of the 2003 heat wave were simulated. The severity of heat waves is described by the so-called cumulative heat wave severity, which is defined as the product of the number of heat waves during a 30-year period and the mean severity of the individual heat waves. The latter is defined as the product of the duration, the mean extent and the mean intensity of the respective heat wave. Most of the changes in the temperature-related extremes during summer are partly associated with corresponding changes in the variation in temperature over the course of a day (diurnal cycle) as well as variations in temperature from day to day. According to Cattiaux et al. (2015), both diurnal variability and day-to-day variability in summer temperature increase under the different RCP scenarios, with extremely strong variations over both time scales occurring more frequently. In western Europe, for instance, diurnal and day-to-day variability both increase by about $10 \%$ under the RCP8.5 scenario, with weaker increases over northern Europe of up to $6 \%$. The increases in variability are primarily linked to a future decrease in surface evapotranspiration as a consequence of drier European summers.

Several extremes related to daily temperature were identified in the SREX report with high confidence for northern Europe (Seneviratne et al. 2012). For instance, the frequency of warm days is very likely to increase, but not as much as in central and southern Europe (Fischer and Schär 2010), there are very likely to be fewer cold days (with daily maximum temperatures below the respective 10th percentile) and a likely increase in the 20-year return levels of annual maximum temperature. There are very likely to be fewer cold nights (Kjellström et al. 2007; Sillmann and Roeckner 2008) and more warm nights (Tebaldi et al. 2006). Heat waves and warm spells are likely to occur more often, last for longer and/or be more intense, but the changes in northern Europe are smaller than in southern Europe, while Scandinavia shows little change at all (Beniston et al. 2007; Koffi and Koffi 2008; Fischer and Schär 2010; Orlowsky and Seneviratne 2012).

\subsection{Precipitation}

Wilhelm May

\subsubsection{Mean Precipitation}

At a global scale, the CMIP5 simulations project increases in precipitation in the tropics as well as at mid and high latitudes, and a decrease in the sub-tropics (Knutti and Sedláček 2012). For the North Sea region, the multi-model ensemble projects an increase in winter and a decrease in summer except for Denmark and southern Norway. This tendency is also evident in the projected changes in precipitation for northern and central Europe based on the CMIP5 simulations presented in Annex I of AR5 (IPCC 2013) for the cold (October through March) and warm (April through September) seasons. For the cold season, the RCP4.5 scenario is characterised by increases of up to $10 \%$ in the North Sea region at the end of the 21 st century, and the changes projected exceed natural variability over the entire region. For the warm season, on the other hand, precipitation is projected to decrease by up to $10 \%$ in England, Belgium, the Netherlands and northern Germany and to increase by up to $10 \%$ in Denmark and southern Norway. However, the changes projected during the warm season do not exceed natural climate variability anywhere across the region. Averaged over northern Europe, the projected increase in precipitation during the cold season ranges from $8 \%(\mathrm{RCP} 4.5)$ to $11 \%(\mathrm{RCP} 8.5)$ for the mid-21st century and from $11 \%$ (RCP4.5) to $20 \%$ (RCP8.5) at the end of the 21 st century (see Table 5.4). Precipitation averaged over northern Europe during the warm season is increased, ranging from 3 to $4 \%$ for the mid-21st century and 5-8\% at the end of the century.

Table 5.4 Projected relative changes in mean precipitation (\%) by the mid- and end of the 21st century (2046-2065 and 2081-2100, with respect to 1986-2005) for northern Europe (see Seneviratne et al. 2012, their Fig. 3.1) for RCP4.5 (42 models) and RCP8.5 (39 models) obtained from the CMIP5 simulations, distinguishing between the cold season (October through March; ONDJFM) and warm season (April through September; AMJJAS)

\begin{tabular}{l|l|r|r}
\hline Period & Season & RCP4.5 & \multicolumn{1}{l}{ RCP8.5 } \\
\hline $2046-2065$ & ONDJFM & $8(3-11)$ & $11(8-15)$ \\
\hline & AMJJAS & $3(2-8)$ & $4(1-10)$ \\
\hline $2081-2100$ & ONDJFM & $11(7-14)$ & $20(15-29)$ \\
& AMJJAS & $5(2-8)$ & $8(2-12)$
\end{tabular}

Data represent the median of the multi-model ensemble of changes and the 25 th and 75 th percentiles of the individual model responses. Adapted from Christensen et al. (2013a, their Table 14.1) and Christensen et al. (2013b, their Table 14.SM.1c), respectively 
During winter some precipitation in the North Sea region falls as snow. As conditions warm, the fraction falling as snow is expected to decrease. According to Brutel-Vuilmet et al. (2013) the CMIP5 simulations are characterised by several snow-related changes in the mid-latitudes of the northern hemisphere at the end of the 21 st century. Between $40^{\circ}$ and $60^{\circ} \mathrm{N}$ the RCP scenarios project a decrease in solid precipitation of about $10 \%$ (RCP2.6) to $30 \%$ (RCP8.5), despite a marked rise in total precipitation at these latitudes. Consistent with this, snow depth declines by about $10 \%$ (RCP2.6) to $40 \%$ (RCP8.5), and the snow season shortens with the decrease ranging from up to a fortnight (RCP2.6) to a month or more (RCP8.5). Räisänen and Eklund (2012) presented consistent results for northern Europe based on an ensemble of regional climate scenarios applying the SRES A1B scenario from the ENSEMBLES project (e.g. van der Linden and Mitchell 2009). They identified future decreases in snowfall and snow depth across all low-altitude parts of northern Europe, including Denmark and southern Norway as part of the North Sea region.

The characteristic changes in precipitation over Europe were also revealed in the multi-model ensemble of high-resolution RCM simulations for Europe used by Jacob et al. (2014). For the RCP4.5 scenario, seasonal mean precipitation in the North Sea region increases in winter and spring by about $10-15 \%$ at the end of the 21 st century (Fig. 5.3). In summer and autumn, on the other hand, precipitation increases (exceeding $5 \%$ ) in south-western Norway, but there is little change in the rest of the North Sea region, ranging between a slight decrease (of less than $5 \%$ ) in the south to a slight increase (of less than $5 \%$ ) in the north. Averaged over the Atlantic region, annual mean precipitation increases slightly (1\%) for RCP4.5 and more notably for RCP8.5 (see Table 5.5). For the RCP4.5
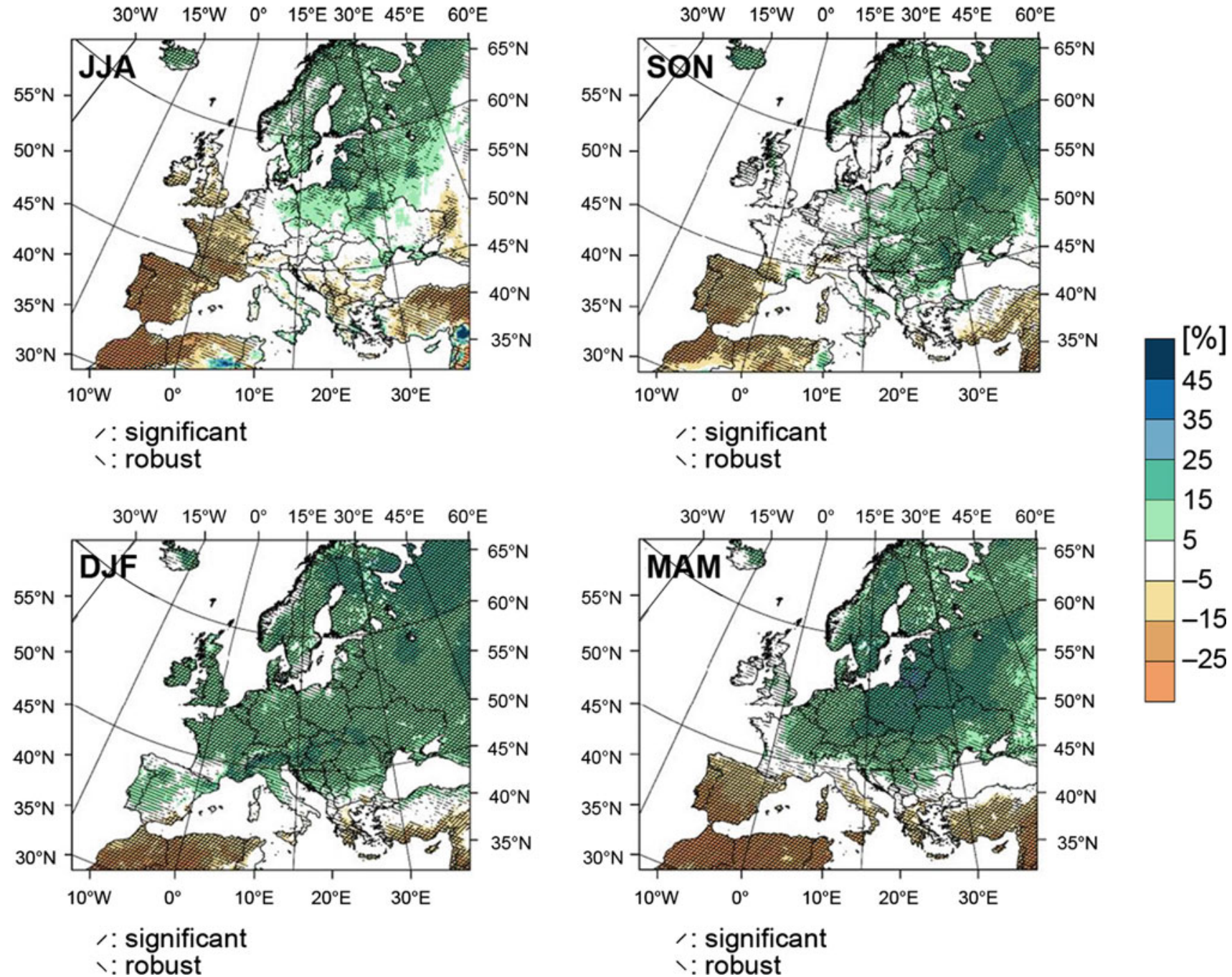

Fig. 5.3 Projected seasonal change in precipitation (\%) based on the RCP4.5 scenario for the period 2071-2100 relative to 1971-2000. Hatched areas indicate regions with robust and/or statistically significant change. From the supplementary material of Jacob et al. (2014) 
Table 5.5 Projected change in precipitation-related variables and indices for the end of the 21st century (2071-2100 with respect to 1971-2000) averaged over the Atlantic region for the RCP4.5 (eight RCM simulations) and RCP8.5 (nine RCM simulations) scenarios

\begin{tabular}{|l|r|r|}
\hline & RCP4.5 & RCP8.5 \\
\hline Annual total precipitation (\%) & $1(-1$ to 6) & $4(1$ to 7$)$ \\
\hline Annual total precipitation where daily precipitation exceeds the 99th percentile in 1971-2000 (\%) & $21(13$ to 44) & $43(32$ to 68)
\end{tabular}

The data represent the median of the multi-model ensemble of changes and the likely range of these changes, defined to include $66 \%$ of all projected changes around the ensemble median. Adapted from Kovats et al. (2014b, their table SM23-3)

scenario, however, one sixth of the different RCM simulations are actually characterised by decreasing precipitation across the Atlantic region.

In Denmark the CMIP5 simulations project increases in seasonal mean precipitation at the end of the 21 st century in all seasons except summer (DMI 2014). For summer, the RCP8.5 scenario projects a decrease of about $17 \%$ but with an inter-model standard deviation of $21 \%$. This scenario projects the strongest increase in winter (18\%), and change in the transition seasons are 10 and $11 \%$, respectively. For annual mean precipitation, the RCP8.5 scenario projects a future increase of about $7 \%$, which is slightly larger than the inter-model standard deviation. Consistent with this, the high-resolution RCM simulations used by Wagner et al. (2013) project future increases in annual mean precipitation of $2-6 \%$ in northern Germany. For the Netherlands, the projections are characterised by an increase in annual mean precipitation of 5-7 \% with little dependence on the strength of impact of the circulation change (KNMI 2014). This is, however, not the case for changes in the seasonal means, where the scenarios with a strong influence of circulation change project stronger changes in precipitation. In winter, the scenarios with strong warming rate project an increase of $30 \%$ by the end of the 21 st century in combination with a strong influence of circulation change and $11 \%$ in combination with a weak impact. In summer, on the other hand, the scenarios with strong warming project reductions of 17 and $4.5 \%$, respectively.

\subsubsection{Precipitation Extremes}

Similar to temperature, changes in the variability of precipitation at time scales of up to a season are more relevant in terms of impact than changes in seasonal or annual precipitation. Examples are heavy rainfall at sub-daily or daily time scales, wet spells of several days duration and extended dry periods lasting from one to several weeks or months. On the basis of daily time series of precipitation, Frich et al. (2002) proposed five different indices describing climate extremes related to precipitation in order to coordinate and standardise the definition of such extremes. Zhang et al. (2011) extended this list of extreme precipitation indices to 12 , also revising some of the definitions of Frich et al. (2002). These indices often focus on relative thresholds that describe the tails of the distribution rather than on physically-based thresholds.

Kovats et al. (2014b) reported on projected changes in the fraction of the annual precipitation originating from extremely wet days (exceeding the 99th percentile of daily precipitation; Zhang et al. 2011). Averaged over the Atlantic region, this is projected to increase by $21 \%(\mathrm{RCP} 4.5)$ to $43 \%$ (RCP8.5) at the end of the 21st century (see Table 5.5).

Jacob et al. (2014) considered projected change in precipitation on very wet days (exceeding the 95th percentile of daily precipitation; Zhang et al. 2011), distinguishing between seasons. At the end of the 21 st century both the RCP4.5 (Fig. 5.4) and RCP8.5 scenarios project significant increases in the intensity of heavy precipitation events over the entire North Sea region and in all seasons. For RCP4.5 the projected increases are typically 5-15\%, while for RCP8.5 the increases are 15-25\% in all seasons except summer. Jacob et al. (2014) also considered future change in very long lasting droughts (defined as the 95th percentile of the length of dry spells) and found no change in the North Sea region for RCP4.5 and a very small increase of 1-2 days in western Europe for RCP8.5.

The CMIP5 simulations have also been used to project change in various precipitation-related extremes, with some referred to in AR5 (Collins et al. 2013). For instance, Sillmann et al. (2013) presented global maps of future change in very high daily precipitation, defined as the 95th percentile of precipitation on wet days. They found pronounced increases in the intensity of heavy precipitation events over western, central and northern Europe at the end of the 21st century for all RCP scenarios considered, with the smallest increases (about $20 \%$ ) for RCP2.6 and the largest (40$70 \%$ ) for RCP8.5. The magnitude of the relative changes in the intensity of heavy precipitation events is considerably greater than the corresponding changes in the average intensity of daily precipitation on all wet days. In southwestern Europe, the intensity of heavy precipitation events is projected to increase despite a projected decrease in average intensity. Consistent with this, Scoccimarro et al. (2013) projected a relatively strong increase in the fraction of precipitation originating from daily precipitation events in the range between the 90th and 99th percentile in western, central and northern Europe. In winter, the contributions of 

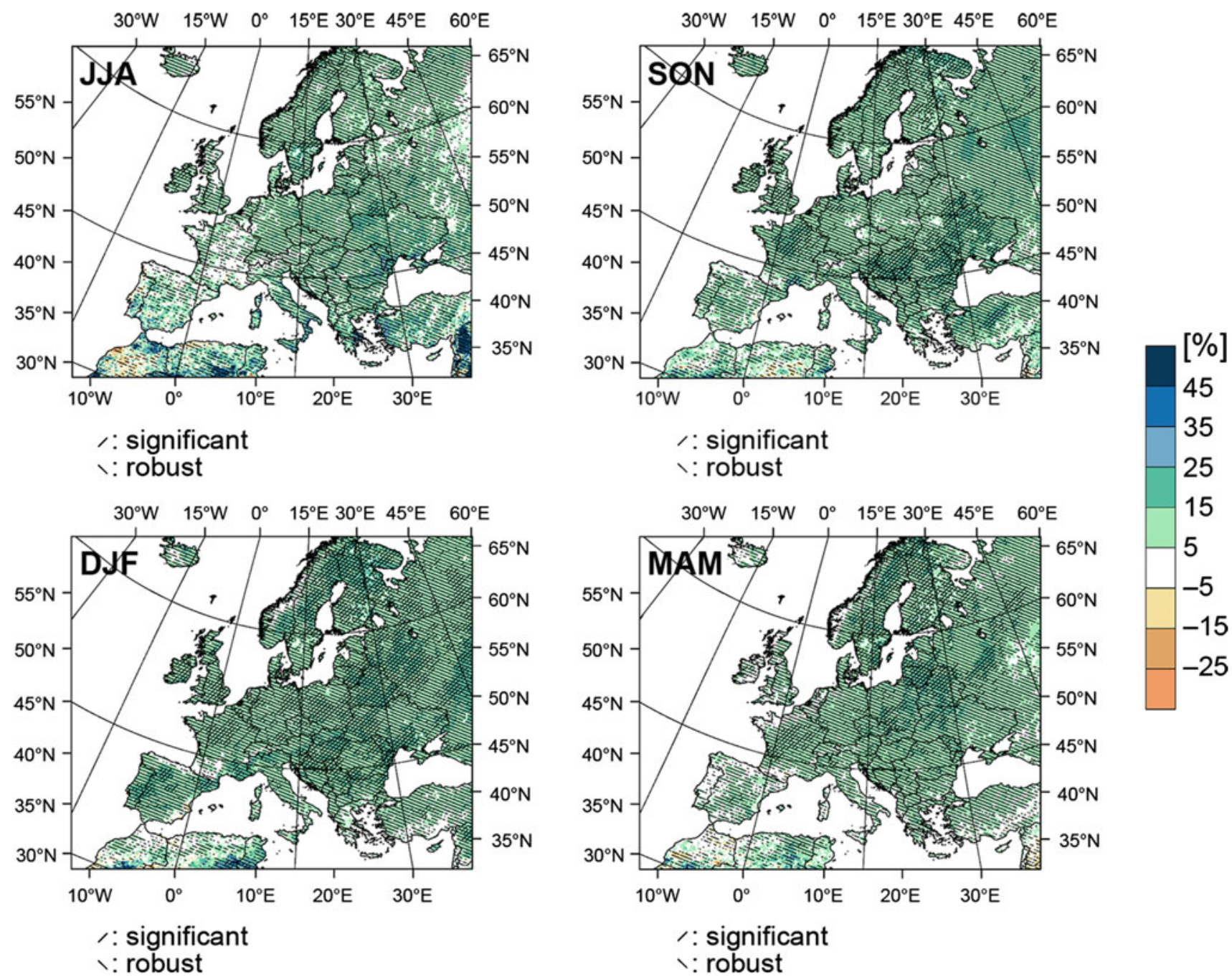

Fig. 5.4 Projected seasonal change in heavy precipitation (\%) based on the RCP4.5 scenario for the period 2071-2100 compared to 1971-2000. Hatched areas indicate regions with robust and/or statistically significant change (Jacob et al. 2014)

the heavy daily precipitation events increase by more than $20 \%$ in these areas of Europe, in summer the increases are typically $10-20 \%$ for RCP8.5. It is only in summer that the intensity of heavy precipitation events increases in those parts of western, central and northern Europe, where average intensity decreases. In winter, the intensity of heavy daily precipitation events and the average intensity both increase in western, central and northern Europe.

Another way to depict the projected changes in heavy daily precipitation events is in terms of the number of days for which future daily precipitation exceeds a particular high threshold for the reference period. Applying this approach to an ensemble of RCM simulations, Wagner et al. (2013) found that for more than $5 \%$ of days, the amounts of daily precipitation exceeded the 95th percentile for the reference period in north-western Germany in the mid-21st century. Instead of a variable threshold, another approach is to consider a particular amount of daily precipitation. Sillmann et al. (2013), for instance, analysed future change in the number of days with at least $10 \mathrm{~mm}$ precipitation and projected an increase in western, central and northern Europe, ranging from about two additional days (RCP2.6) to about six additional days (RCP8.5) at the end of the 21st century. In contrast to Sillmann et al. (2013), who based their analysis on data covering the entire year, KNMI (2014) distinguished between winter and summer and used different thresholds for the two seasons, $10 \mathrm{~mm}$ in winter and $20 \mathrm{~mm}$ in summer. In winter, KNMI (2014) found more days with at least $10 \mathrm{~mm}$ precipitation in the Netherlands, with increases of $14-24 \%$ for the two scenarios with moderate future warming and 30-60\% for the two scenarios with strong future warming. For each of the two rates of future warming the strongest increases are associated with a strong influence of circulation change (i.e. a more predominantly westerly 
flow). In summer, however, the situation is different, with more days with at least $20 \mathrm{~mm}$ precipitation for the two scenarios with a weak influence of circulation change. In the case of a strong influence of circulation change (i.e. a more predominantly easterly flow), the increase in the number of days with at least $20 \mathrm{~mm}$ precipitation is less pronounced in some parts of the Netherlands and the number of such days is even reduced in others.

Over the last couple of years, change in precipitation at sub-daily time scales has also become the subject of scientific study. Lenderink and van Meijgaard (2008), for instance, investigated the potential future change in various extremes of hourly and daily precipitation in central Europe during summer in a scenario simulation with a state-of-the-art RCM. As well as identifying much stronger relative increases in hourly precipitation extremes (19-39\% for different percentiles) than in daily precipitation extremes (9-20\% for different percentiles) they found that the projected increases in hourly precipitation extremes exceeded $7 \%$ per degree of warming, which would be expected according to the Clausius-Clapeyron equation, that is, about $14 \%$ per ${ }^{\circ} \mathrm{C}$ for the 99.9 th percentile of hourly precipitation. According to KNMI (2014) the summer maximum hourly precipitation is projected to increase by $8-19 \%$ for the two moderate warming scenarios and by $19-45 \%$ for the two strong warming scenarios by the end of the 21 st century. In this case, the difference in the influence of circulation change had little effect. The magnitude of the projected absolute changes in extreme hourly precipitation typically simulated by RCMs, however, is probably smaller than what can actually be expected in the future. Kendon et al. (2014) demonstrated that a numerical model operated at a spatial resolution of $1.5 \mathrm{~km}$, which is typical for numerical weather prediction, gives much stronger changes in hourly precipitation extremes during summer than a model operated at a coarser resolution of $12 \mathrm{~km}$. Nevertheless, the relative increases in extreme hourly precipitation of $45 \%$ for the warm scenario combined with a strong impact of the circulation change are of the same order of magnitude as the relative increases projected over the southern part of the UK by Kendon et al. (2014).

Kharin et al. (2013) depicted future changes in extreme daily precipitation events on the basis of the CMIP5 simulations by means of the 20-year return levels for annual maximum daily precipitation. At the end of the 21 st century they found an increase in the 20-year return levels of about 10-20\% in the North Sea region for RCP8.5. This means that the annual maximum daily precipitation amounts with a return period of 20 years under present-day climate conditions are likely to occur about every $10-14$ years in the future. Nikulin et al. (2011) analysed future changes in 20 -year return levels for maximum daily precipitation in winter and summer, when computing the 20-year return levels combining six RCM simulations for Europe. In summer they found changes in the 20-year return level in the range 10-20\% in the North Sea region at the end of the $21 \mathrm{st}$ century, and in winter values of $15-30 \%$. As a consequence, waiting times for a 20 -year event under present-day climate conditions are notably more reduced in winter (about 8-12 years) than summer (about 12-16 years).

The projected intensification of heavy daily precipitation in the North Sea region is accompanied by an increase in the mean duration of periods with consecutive dry days. According to Sillmann et al. (2013), the average length of periods with consecutive dry days increases by 1-5 days for the North Sea region under RCP8.5. For RCP4.5, however, there is little change in the average length of periods with consecutive dry days. This is consistent with the findings of Wagner et al. (2013), who identified only very small changes in the average length of periods with consecutive dry days (in this case lasting more than five days) in northern Germany for the mid-21st century under the SRES A1B scenario.

The SREX report (Seneviratne et al. 2012) identified with high confidence very likely increases in both the intensity and frequency of heavy daily precipitation events in northern Europe, accompanied by increases in the fraction of the days with precipitation, for which the daily precipitation exceeds $10 \mathrm{~mm}$, north of $45^{\circ} \mathrm{N}$ in winter (Frei et al. 2006; Beniston et al. 2007; Kendon et al. 2008). The report also identified a likely increase in the 20-year return levels of daily precipitation in northern Europe.

\subsection{Cyclones and Winds}

Anette Ganske, Gregor C. Leckebusch, Wilhelm May

\subsubsection{Cyclones}

Zappa et al. (2013) analysed future projections of the occurrence of extratropical cyclones in the North AtlanticEuropean sector on the basis of 19 CMIP5 model simulations for both the RCP4.5 and RCP8.5 scenarios. In this study, cyclones were identified and tracked using the objective feature tracking algorithm developed by Hodges (1999). During winter (December through February) the authors identified a tri-polar pattern over Europe with an increase in storm track density over the eastern North Atlantic centred over the British Isles and the North Sea and decreases centred around Iceland and over the Mediterranean Sea (Fig. 5.5). These changes indicate an extension of the Atlantic storm track to the northeast in combination with a narrowing of the storm track over western Europe. These results are in line with the corresponding changes in storm track density on the 
(a)

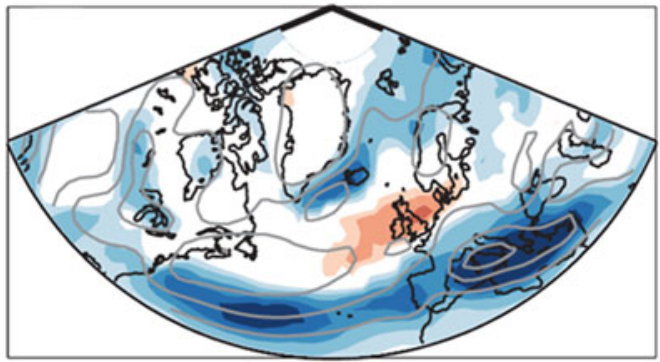

(b)

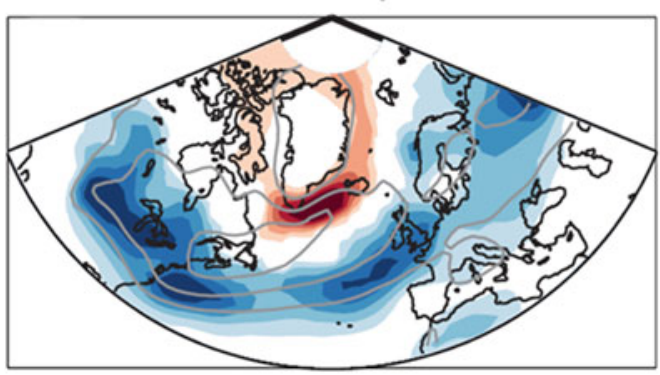

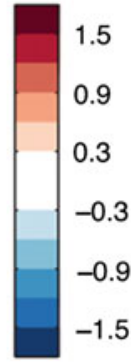

$-1.5$

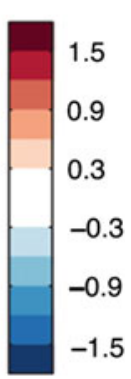

Fig. 5.5 Projected change in mean track density for winter (December through February, DJF; upper panel) and summer (June through August, JJA; lower panel) based on the RCP8.5 scenario from 19 CMIP5 simulations. Units are number of cyclones per month per unit area. Only responses statistically significant at the $5 \%$ level are shown (Zappa et al. 2013)

basis of the CMIP3 simulations (Ulbrich et al. 2008). The RCP8.5 scenario gives increases in the range 0.6-1.2 cyclones per month in winter at the end of the 21 st century over the British Isles, the North Sea and Denmark and only small changes over western Europe. For the RCP4.5 scenario the corresponding changes range between 0.3 and 0.9 cyclones per month. Considering only intense cyclones with pressures below $980 \mathrm{hPa}$ during their lifetimes, Mizuta (2012) found increases of about 0.1 cyclones per month centred over the British Isles for the RCP4.5 scenario on the basis of 11 CMIP5 model simulations. During summer (June through August), on the other hand, Zappa et al. (2013) found an increase in storm track intensity centred between Iceland and southern Greenland and a decrease centred west of the British Isles extending further into the North Sea region (Fig. 5.5). This decrease indicates a marked reduction in the number of cyclones at the southern flank of the storm track over western Europe. For the RCP8.5 scenario the number of cyclones in summer is projected to decrease by $0.6-1.5$ cyclones per month over the North Sea and by 0.6-0.9 cyclones per month over western and northern Europe. The RCP4.5 scenario gives increases in the range $0.3-0.6$ cyclones per month over the North Sea and about 0.3 cyclones per month over western Europe.
Harvey et al. (2012) assessed the magnitude of projected changes in the Atlantic storm track for both the CMIP3 (SRES A1B scenario) and CMIP5 (RCP4.5 scenario) simulations relative to its typical interannual variations. The storm track was defined via band-pass filtered (2-6 days) variations in the daily surface pressure fields. The authors found that the multi-model ensemble changes in the Atlantic storm track in winter largely agree between the CMIP3 and CMIP5 simulations, when scaling with the respective changes in global mean temperature. The changes simulated by individual models, however, typically have a magnitude similar to the variability at decadal time scales and are locally as strong as the interannual variability. In some parts of the North Atlantic, up to $40 \%$ of the climate models considered were characterised by a positive change in storm track density, exceeding half the magnitude of the interannual variability. With respect to the projected changes in cyclone track density, Ulbrich et al. (2013) noted that part of the uncertainty regarding regional trends in cyclone activity can be related to the choice of a particular method for identification and tracking of cyclones. While different methodologies gave consistent results for intense cyclones, i.e., an increase in the number of cyclones over western Europe in winter, they led to opposing results for weak cyclones with either an increase or decrease in the number of cyclones. According to Chang et al. (2012), the overall tendency of a poleward shift of the Atlantic storm track under future climate conditions is accompanied by an upward extension of the storm track into the upper troposphere and lower stratosphere under the projected global warming, again consistent for the CMIP3 and the CMIP5 simulations.

In a recent review on storminess over the North Atlantic and north-western Europe, Feser et al. (2015) summarised projected changes in both storm frequency and storm intensity on the basis of numerous recent studies that assessed potential future change in these two aspects of storms on the basis of climate scenario simulations with different kinds of models. For the North Sea region, the review considered results from 16 studies published between 1997 and 2013 based on GCMs (either coupled to an ocean model or atmosphere-only) and RCMs with different scenarios for anthropogenic greenhouse gas forcing prescribed. Most of these studies (9 out of 11) showed a future increase in storm frequency, while two found a decrease. Likewise, 10 out of 11 studies showed a future increase in storm intensity; no trend was found in the remaining study. The same trends were also identified over the North Atlantic south of about $60^{\circ} \mathrm{N}$, while over northern and central Europe about the same number of studies projected either increases or decreases in storm frequency. 


\subsubsection{Mean Wind Speeds}

The mean winds near the surface (at $10 \mathrm{~m}$ height) in the North Sea region are characterised by a clear gradient between the North Sea and the adjacent land areas with considerably higher wind speeds over the ocean than over land, particularly during winter (e.g. Kjellström et al. 2011).

In contrast to other meteorological variables such as precipitation and temperature, very few studies have assessed potential future changes in near-surface winds in response to anthropogenic climate forcing on the basis of scenario simulations originating from GCMs. McInnes et al. (2011) analysed future changes in mean wind speeds at $10 \mathrm{~m}$ at a global scale on the basis of the CMIP3 simulations based on the SRES A1B scenario and found an increase in mean wind speeds over both the North Sea and the adjacent land areas in winter at the end of the 21 st century, while in summer a notable increase was found over the North Sea only. On an annual basis, mean wind speeds are projected to increase over the entire North Sea region; with the projected changes in mean wind speed typically exceeding $10 \%$. Despite an overall tendency of increasing mean wind speed in the North Sea region, McInnes et al. (2011) identified marked variations between individual models regarding the sign of the change, particularly in the southern North Sea region. In a recent study, Sterl et al. (2015) analysed projected change in annual mean wind speeds at $10 \mathrm{~m}$ over the southern North Sea region for the RCP4.5 and RCP8.5 scenarios using one GCM. In contrast to the overall tendency obtained from the CMIP3 simulations, Sterl et al. (2015) found decreases in annual mean wind speed over the entire region, with little difference between the two scenarios.

More studies exist in which potential future changes in near-surface winds in response to anthropogenic climate forcing for selected regions or continents have been assessed on the basis of scenario simulations with RCMs. The finer spatial resolution not only adds regional detail to the simulations, which is important when looking at the North Sea region, but also affects the magnitude of the projected changes, particularly regarding extreme wind speeds (Winterfeldt and Weisse 2009). This is especially the case when RCMs are applied at very high horizontal resolution. Pryor et al. (2012) showed, for instance, that for the RCA3 RCM an increase in horizontal resolution from 50 to $6.25 \mathrm{~km}$ leads to an overall increase in simulated mean near-surface wind speed of $5 \%$ averaged over southern Scandinavia, while the 50 -year return level of wind speeds and wind gusts increases by over 10 and $24 \%$, respectively.

Kjellström et al. (2011) analysed potential future change in mean wind speed on the basis of an ensemble of simulations with the RCA3 RCM driven by six different GCMs for the SRES A1B scenario. These projections are characterised by a small (up to $0.25 \mathrm{~ms}^{-1}$ ) increase in mean wind speed in the North Sea region in winter but a decrease over land areas and a small increase over the southern part of the North Sea. In particular in winter, the regional distributions of the projected changes vary considerably, both in sign and in strength between the RCA simulations driven by different GCMs. In a similar type of study based on an ensemble of climate projections with the HIRHAM RCM driven by three different GCMs for either the SRES B2 or the SRES A1B scenario, Debernard and Røed (2008) found increases in annual mean wind speed in the North Sea region, reaching up to $2 \%$ over ocean areas.

\subsubsection{Wind Extremes}

For extremes of near-surface winds, defined via the 99th percentile of daily mean wind speed, the CMIP3 simulations show an overall slight increase (up to $5 \%$ ) in the North Sea region during winter and an overall slight decrease (up to $5 \%$ ) during summer (McInnes et al. 2011). In this, the projected changes in extreme wind speed are markedly less pronounced than the corresponding changes in mean wind speed when normalised with the climatological values for present-day climate conditions. De Winter et al. (2013) analysed projected changes in annual maximum near-surface wind speed based on scenario simulations with 12 GCMs from CMIP5 for both the RCP4.5 and RCP8.5 scenarios. In contrast to McInnes et al. (2011), they analysed the scenarios from each GCM separately instead of the multi-model ensemble mean. The different GCMs simulated very different changes in the North Sea region, with some models giving either increases or decreases in the intensity of wind extremes over most of the North Sea region and others giving increases over the northern part of the North Sea region and decreases in the southern part. For the RCP8.5 scenario the projected changes typically vary in the range -1.5 to $1.5 \mathrm{~ms}^{-1}$. The individual GCMs simulate not only very different future changes in the intensity of extreme winds, but also very different distributions of the intensity of extreme winds, both with regard to the location of the peak and with regard to the width of the respective probability density functions aggregated over the North Sea.

Donat et al. (2011) presented the projected changes in the intensity of wind extremes (defined via the 98th percentile of daily maximum wind speed) for six different GCMs from CMIP3 for the SRES A1B scenario individually, finding very different changes in the intensity of extreme winds in the North Sea region. The multi-model ensemble mean showed intensified extreme winds in the range 0.25$0.75 \mathrm{~ms}^{-1}$ in the North Sea region at the end of the $21 \mathrm{st}$ century. Donat et al. (2011) also considered a number of 
scenario simulations with different RCMs driven by these GCMs, which were part of the ENSEMBLES project (Van der Linden and Mitchell 2009). They found that dynamical downscaling contributed to the uncertainty of the projected changes, as RCMs driven with identical large-scale boundary conditions simulated quite different changes in the intensity of wind extremes.

Nikulin et al. (2011), on the other hand, considered six different scenario simulations with one particular RCM (RCA3) driven by global scenario simulations with six different GCMs for the SRES A1B scenario. Consistent with the studies above, Nikulin et al. (2011) also found very different changes in the 20-year return levels of daily maximum wind speeds in the North Sea region at the end of the 21 st century for the individual RCM simulations. The multi-model ensemble means were characterised by a general tendency of more intense wind extremes in the North Sea region. Similarly, Gaslikova et al. (2013) analysed four different scenario simulations with the CCLM RCM driven by four different global scenario simulations with one particular GCM (two realisations of both the SRES B1 and the SRES A1B scenarios). The projected changes in the intensity of extreme winds (defined as the 99th percentile of annual maximum daily wind speeds) over the North Sea were also found to vary considerably between the four scenarios. This was particularly the case for the scenarios driven by the two realisations of the global simulations, where one realisation gave weaker wind extremes over the northern part of the North Sea. The A1B scenario resulted in notably stronger increases in the intensity of extreme winds than the B1 scenario. The multi-model ensemble means are characterised by more intense wind extremes to the south of $58^{\circ} \mathrm{N}$, ranging between 0.2 and $0.4 \mathrm{~ms}^{-1}$ over most of the area at the end of the 21 st century.

The differences between the two realisations over the North Sea are also revealed in the time series of the change in the intensity of wind extremes at different locations in the North Sea for the four different scenario simulations (Fig. 5.6). At the central North Sea location two of the realisations (A1B_2 and B1_2) simulated weaker wind extremes during the entire 21 st century, while at the two locations in the German Bight this tendency is only apparent during the first half of the 21st century. The other two realisations (A1B_1 and B1_1), on the other hand, simulated stronger wind extremes during the course of the 21 st century. The time series also illustrate the marked internal variability at multi-decadal time scales, making it difficult to identify systematic differences between the SRES A1B and B1 scenario simulations at these locations. For individual 30-year periods, however, marked differences between the A1B and B1 scenarios can occur, i.e., the two realisations A1B_1 and B1_1 at the end of the 21st century.

\subsubsection{Wind Direction}

McInnes et al. (2011) analysed projected changes in the direction of the mean winds at a global scale on the basis of the CMIP3 simulations. For the North Sea region, they found very small changes in mean wind direction in winter but in summer anticlockwise changes across the entire region, exceeding $15^{\circ}$ in the southern areas. The

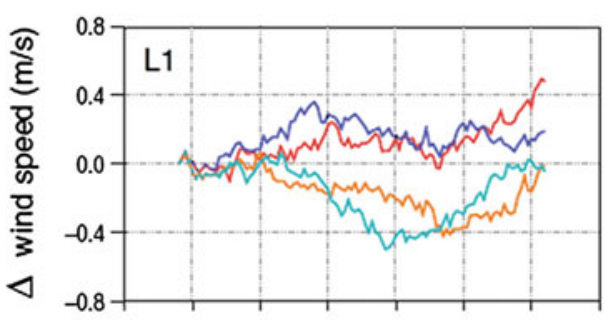

A1B_1 B1_1 A1B_2 B1_2
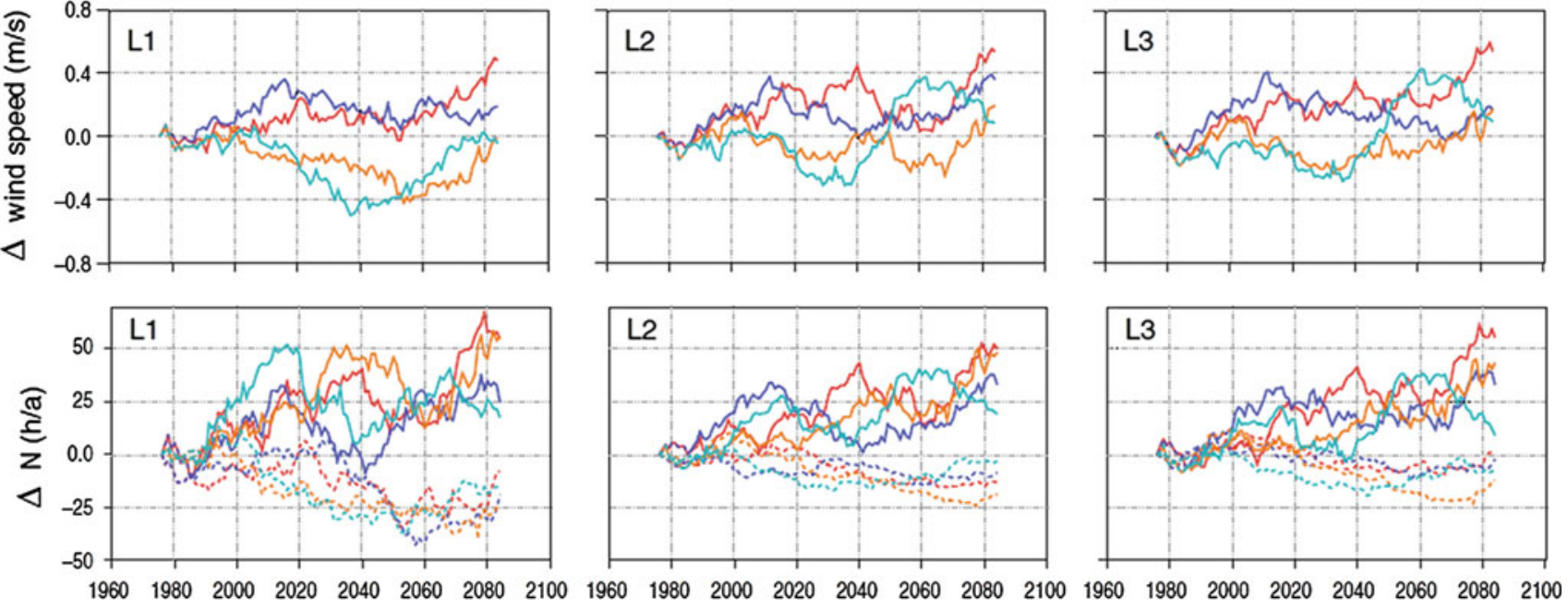

Fig. 5.6 Changes in 30-year running means with respect to 19611990 for four different RCM scenario simulations for the annual 99th percentile wind speeds (upper row) and (lower row) the annual frequencies of strong $\left(\geq 17.2 \mathrm{~ms}^{-1}\right)$ westerly winds $\left(165-345^{\circ}\right.$; solid

lines) and strong easterly winds $\left(345-165^{\circ}\right.$; dashed lines $)$ at a site in the central North Sea (L1) and two sites in the German Bight (L2 and L3) (adapted from Gaslikova et al. 2013, their Fig. 8) 
anticlockwise changes in mean wind direction in the southern North Sea region are consistent between most of the scenario simulations considered.

De Winter et al. (2013), on the other hand, analysed projected changes in the direction of strong winds over the North Sea on the basis of 12 GCMs contributing to CMIP5 for both the RCP4.5 and RCP8.5 scenarios. Strong winds were defined as the annual maxima of daily mean wind speeds and two areas were distinguished, one in the northern part of the North Sea and the other in the southern part. The authors found a common tendency towards less frequent strong winds from south-eastern directions and more frequent strong winds from south-western and western directions in the latter half of the 21 st century in both regions for both scenarios. However, it should be noted that due to the rarity of strong wind events the wind direction statistics are characterised by a high degree of variability, which affects the robustness of the projected changes. These changes in the predominant wind directions are consistent with the findings of Donat et al. (2010), who considered storm days (based on daily maximum wind speeds) over western Europe on the basis of six GCMs contributing to CMIP3 for the SRES A1B scenario, and by Sterl et al. (2009) on the basis of a multi-member ensemble of scenario simulations for the SRES A1B scenario with one particular GCM. The projected changes from south-easterly to more south-westerly and westerly winds could indicate a poleward shift in the storm track, because in the North Sea region a storm following a northern track is associated with predominantly westerly winds, while a storm following a more southern track mainly produces south-easterly winds. Both the CMIP3 and CMIP5 simulations are characterised by corresponding changes in the storm track in the North Sea region (e.g. Harvey et al. 2012; Zappa et al. 2013).

Gaslikova et al. (2013) used an ensemble of four different scenario simulations with the CCLM RCM driven by four different global scenario simulations with one particular GCM (two realisations of both the SRES B1 and SRES A1B scenarios) to analyse projected changes in the direction of wind speeds of at least $17.2 \mathrm{~ms}^{-1}$ (corresponding to $8 \mathrm{Bft}$ ) at several locations in the North Sea region. They found a general tendency of more frequent strong westerly winds and of less frequent easterly winds in the central North Sea as well as in the German Bight in the course of the 21 st century (Fig. 5.6). The decreases in the frequency of strong easterly winds are more pronounced in the German Bight than in the central North Sea, while increases in the frequency of strong westerly winds are similar at all locations. The time series of the projected changes for the four scenario simulations reveal both strong temporal variability at multi-decadal time scales and notable differences between the individual scenario simulations, illustrating the important role of internal variability for regional assessments of future change in the characteristics of storms.

\subsection{Radiation and Clouds}

\section{Burkhardt Rockel, Wilhelm May}

Few recent publications describe projected changes in radiation and clouds. Also, the RCMs and GCMs used to derive these projections, the emission scenarios used in the projections, and the time periods analysed are quite diverse. The projected changes are presented separately for solar and terrestrial radiation as well as for cloud cover, with similarities between these changes highlighted. The numbers presented in this section are typically estimated from the geographical distributions that cover a much larger area than the North Sea region, such as the globe or the entire European continent.

\subsubsection{Solar Radiation}

For annual mean net downward solar radiation at the surface, all studies show a distinct pattern with a decrease in the northern North Sea region and an increase in the south. This tendency is found regardless of which climate model or scenario is used or which time period is considered and so can be considered a robust result. The magnitude of the projected changes in the two areas varies between studies, however.

With increasing numbers of climate scenario simulations available from different coupled climate models, estimates based on a multi-model ensemble are often taken into account. Henschel (2013), for instance, considered results from 39 GCMs from CMIP5 for the RCP8.5 scenario and found a median decrease of about $0.1 \mathrm{Wm}^{-2}$ per year for the southern part of the North Sea region for the multi-model ensemble, corresponding to a decrease of about $4 \mathrm{Wm}^{-2}$ by the middle of the 21 st century. In contrast, Henschel (2013) did not find any significant trend for the northern North Sea region (north of about $58^{\circ} \mathrm{N}$ ) until the middle of the $21 \mathrm{st}$ century and so did not give any estimate of the change at that point in time.

Trenberth and Fasullo (2009) and Zhou et al. (2009) both considered results from multi-model climate simulations for the SRES A1B scenario to assess projected change until the end of the 21 st century. However, the two studies considered different time periods and different parts of the atmosphere. Trenberth and Fasullo (2009) analysed projected change in annual mean net solar radiation at the top of the atmosphere and found an increase in absorbed solar radiation of up to $6 \mathrm{Wm}^{-2}$ in the southern North Sea region and a decrease of 
up to $1.5 \mathrm{Wm}^{-2}$ in the northern region in the period 2000 2100. Zhou et al. (2009) analysed solar radiation at the surface and found an increase in net surface solar radiation of up to $4 \mathrm{Wm}^{-2}$ in the southern North Sea region and a decrease of up to $6 \mathrm{Wm}^{-2}$ in the north for 2080-2099 relative to $1900-1919$.

Ruosteenoja and Räisänen (2013) analysed projected changes in solar radiation from the CMIP3 multi-model ensemble for the SRES A1B scenario by the end of the $21 \mathrm{st}$ century, distinguishing between seasons. In their supplemental material, Ruosteenoja and Räisänen (2013) also presented changes by the end of the 21 st century for the SRES A2 and B1 scenarios as well as changes by the middle of the 21st century (2020-2049) for the SRES A1B scenario. In contrast to the previously mentioned studies, Ruosteenoja and Räisänen (2013) presented changes relative to the present-day climate (1971-2000) rather than absolute changes. According to their estimates, a relative reduction of $15 \%$ at about $60^{\circ} \mathrm{N}$ corresponds to a decrease of less than $3 \mathrm{Wm}^{-2}$. According to their results, the pattern of projected changes at the middle of the 21 st century varies little with season except for winter with a decrease in solar radiation over almost the entire North Sea region and a strongest decrease of about $5 \%$. During summer, on the other hand, solar radiation is increased almost everywhere, with a strongest increase of about $2.5 \%$. The variations between

(a)

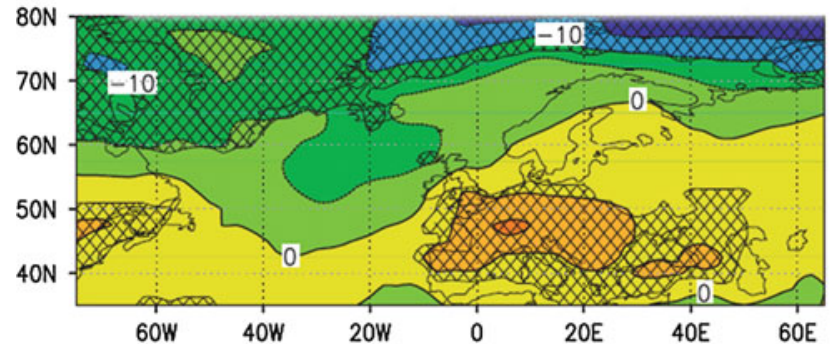

(b)

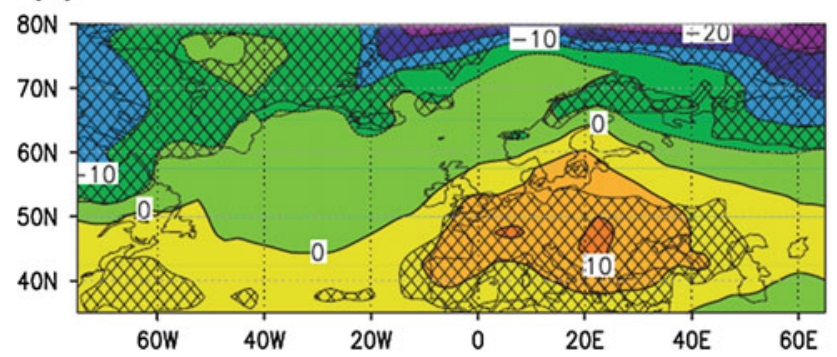

Fig. 5.7 Seasonal change in incident solar radiation (\%) from 19712000 to 2070-2099 under the SRES A1B scenario as an average of 18 GCMs: a summer, b autumn, c winter, and d spring. Areas where more than $85 \%$ of the models (at least 16 of $18 \mathrm{GCMs}$ ) agree on the sign of season are more pronounced at the end of the 21 st century than for the mid-century. During both summer and autumn the characteristic north-south structure is evident with a decrease in solar radiation in the northern part (about $5 \%$ ) of the North Sea region and an increase in the south (about $10 \%$; Fig. 5.7). During winter, on the other hand, solar radiation is reduced across the entire North Sea region, particularly in the eastern part with reductions of about $10 \%$, and over $15 \%$ in the north-eastern part. Consistent with this seasonal variation in the projected changes in solar radiation, KNMI (2014) reported pronounced increases in solar radiation in the Netherlands during summer, of 5.5$9.5 \%$ at the end of the 21 st century for the scenarios with a strong influence of circulation change (i.e. scenarios with more frequent high-pressure systems). The projected changes in annual mean solar radiation in the Netherlands are small, ranging from -0.8 to $1.4 \%$ for the different scenarios.

Ruosteenoja and Räisänen (2013) found very similar changes for the SRES A2 scenario, for which in contrast to the A1B scenario forcing by anthropogenic sulphate aerosol is not reduced during the latter half of the 21st century, while the water vapour content of the atmosphere is further enhanced due to the stronger global warming. This led the authors to conclude that the projected changes in solar radiation are mainly caused by changes in meteorological conditions, principally changes in cloudiness.

\section{(c)}

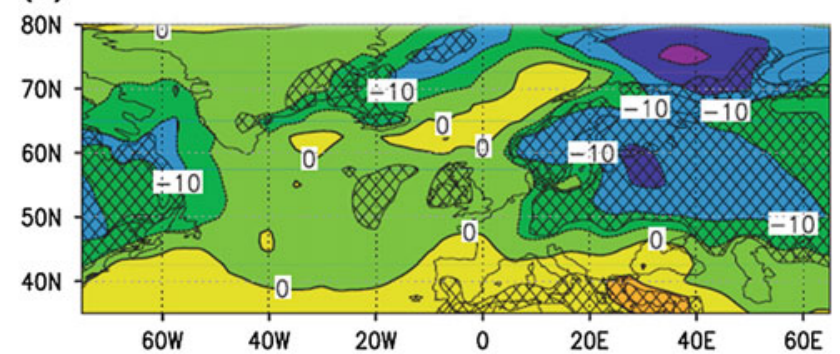

(d)

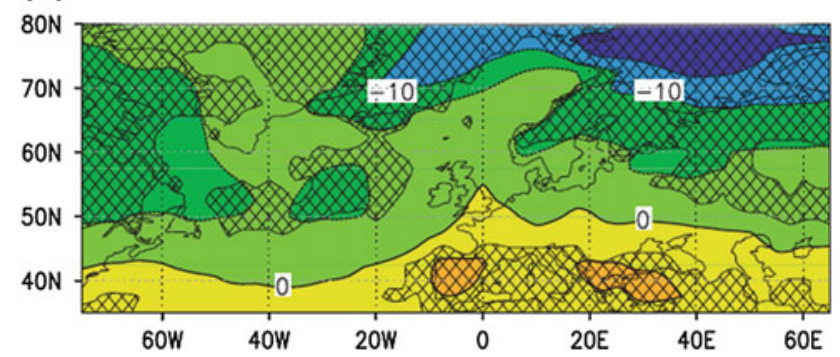

the change are hatched. The contour interval is $5 \mathrm{Wm}^{-2}$; negative changes are marked by warm colours (yellow, orange and red) and positive changes by cold colours (green, blue and purple) (Ruosteenoja and Räisänen 2013) 


\subsubsection{Terrestrial Radiation}

Compared to solar radiation there are even fewer studies assessing projected changes in terrestrial radiation. This could be considered surprising, since terrestrial radiation plays an important role in the greenhouse effect. Zhou et al. (2009) found, for instance, an increase in annual mean terrestrial radiation across the entire North Sea region, with the increase ranging from $14 \mathrm{Wm}^{-2}$ in the western part to $21 \mathrm{Wm}^{-2}$ in the eastern part by the end of the 21 st century. Wild et al. (1997) found a similar pattern with increases of $5-10 \mathrm{Wm}^{-2}$. Trenberth and Fasullo (2009), who in contrast to other studies considered changes in radiation at the top of the atmosphere, found a decrease in annual mean outgoing terrestrial radiation of about $1.5 \mathrm{Wm}^{-2}$ over the North Sea and about $3 \mathrm{Wm}^{-2}$ over adjacent land areas.

\subsubsection{Cloud Cover}

Consistent with the projected changes in annual mean net solar radiation at the surface, the aforementioned studies show a distinct pattern with a projected increase in cloud cover over the northern part of the North Sea region and a decrease over the southern part. This can be taken as a robust result, given the different climate models, scenarios and time periods considered. Nevertheless, the magnitude of the projected changes in these two areas does vary between studies. This finding is also supported by the recent RCP scenario simulations. As shown by Collins et al. (2013), both the RCP4.5 and RCP8.5 scenarios give a decrease in the annual mean cloud cover fraction, of up to $5 \%$ in the southern part of the North Sea region by the end of the 21st century for RCP8.5. Moreover, the projected changes are generally weaker (and less significant) over the North Sea itself than over the adjacent land areas.

Zhou et al. (2009) and Trenberth and Fasullo (2009) found a less pronounced effect on cloud cover in the northern part of the North Sea region than in the south. They found a slight increase of up to 0.5 and $0.75 \%$, respectively, in the northern part, and a considerably stronger decrease of up to $3 \%$ in the southern part. Wild et al. (1997) and Henschel (2013), on the other hand, found a similar amount of change in both areas; about a $2 \%$ increase (decrease) in cloud cover over the northern (southern) part of the North Sea region by the mid-21st century. As these changes are the median from 39 GCMs for the RCP8.5 scenario, these estimates may be considered robust, with two-thirds of the climate models agreeing on a reduction in cloud cover over the southern part of the North Sea region. Consistent with the projected changes in solar radiation, Henschel (2013) did not find any significant trends in cloud cover north of $58^{\circ} \mathrm{N}$.
A study by Räisänen et al. (2003) permits a closer look at the North Sea region, as it is based on a set of regional climate simulations for Europe with the RCAO RCM, with lateral boundary conditions originating from two different GCMs for both the SRES A2 and B2 scenarios. By the end of the 21 st century they found an increase in annual mean cloud cover of up to $8 \%$ in the northern part of the North Sea region and a decrease of up to $8 \%$ in the southern part. The projected changes in cloud cover are particularly strong during summer, with a typical reduction of 12-20\% in the southern part of the North Sea region, depending on the driving GCM and the scenario used. In the northern part, on the other hand, cloud cover typically increases by 4 $12 \%$. In this, the projected future changes during summer are considerably stronger than during winter. Furthermore, the general structure of the patterns of projected change varies little between the different simulations in summer, emphasising the robustness of these projections. In winter, on the other hand, the patterns of simulated changes in cloud cover are strongly affected by the choice of driving GCM. While the simulations driven by HadAM2H project an increase in cloud cover over all land areas with the exception of the British Isles, the simulations driven by ECHAM4/OPYC project a slight decrease in most of this area. The only exception is the respective simulation for the SRES B2 scenario with enhanced cloud cover over western Europe. According to these results, the projected changes in cloud cover during winter are not as robust as those during summer, presumably owing to the greater uncertainty in the projected changes in the large-scale circulation over Europe due to natural climate variability.

\subsubsection{Summary}

Considering all the results reported here, a line of zero change can be roughly drawn from the Firth of Forth to the Skagerrak with a tendency for net solar radiation to decrease (increase) in the region to the north (south) of this line. Consistent with this the same zero-line separates areas with an increase (decrease) in cloud cover in the northern (southern) part of the region.

As mentioned in the introductory paragraph, the actual numbers given here for the North Sea region have been estimated from the corresponding geographical part presented in the respective studies, with most of them covering the entire globe. A study on the projected changes in radiation and clouds focusing on the North Sea region is still missing. With the multi-model ensemble of regional climate simulations for Europe, which have become available through CORDEX (Jacob et al. 2014), such a study might be undertaken in the future. Ruosteenoja and Räisänen (2013) 
took a first step in this direction by considering the changes of the solar radiation for northern and southern Europe separately. Given the importance of the projected changes in cloud cover in the North Sea region, further investigations on the changes in specific cloud properties, i.e. the vertical distribution with low-, mid and high-level clouds or the phase of the clouds (liquid and ice), might help to understand the physical mechanisms behind the projected changes.

\subsection{Conclusions}

\section{Wilhelm May}

The climate projections considered in this chapter reveal changes in the state of the atmosphere in the North Sea region, both in the free atmosphere and near the surface. The changes mostly concern conditions at the end of the $21 \mathrm{st}$ century (with the end of the 20th century or the turn of the 20th and the 21st centuries as the baseline), although some relate to the mid-21st century. They comprise:

- Amplification and an eastward shift in the pattern of NAO variability in autumn and winter.

- Changes in the storm track with increased cyclone density over western Europe in winter and reduced cyclone density on the southern flank in summer.

- More frequent strong winds from westerly directions and less frequent strong winds from south-easterly directions.

- A marked mean warming of $1.7-3.2{ }^{\circ} \mathrm{C}$ for different scenarios, with stronger warming in winter than in summer and relatively strong warming over southern Norway.

- Intensified extremes related to daily maximum temperature and reduced extremes related to daily minimum temperature, both in terms of strength and frequency.

- An increase in mean precipitation during the cold season and a reduction during the warm season.

- A pronounced increase in the intensity of heavy daily precipitation events, particularly in winter.

- A considerable increase in the intensity of extreme hourly precipitation in summer.

- An increase (decrease) in cloud cover in the northern (southern) part of the North Sea region, resulting in a decrease (increase) in net solar radiation at the surface.

It should be noted that the uncertainty ranges of the future changes projected by the climate scenarios vary between the different meteorological variables. The uncertainty range is particularly large for the projected changes in wind speed and in wind direction, both for mean winds and for wind extremes. Hence, the projected changes in wind characteristics are typically within the range of natural variability and can even have opposite signs for different scenarios either simulated by different climate models or for different future periods.

The projected changes in future climate presented here for the North Sea region have typically been extracted from geographical distributions for either the entire globe, when scenario simulations with GCMs are considered, or for Europe, when scenario simulations with RCMs are used. In some of the respective studies, however, different parts of Europe were considered separately, typically distinguishing between northern and southern Europe. With the multi-model ensemble of regional climate simulations for Europe, which have become available through CORDEX (Jacob et al. 2014), such studies with a special focus on the North Sea region could become available in the near future. The studies considered here vary widely in the choice of underlying scenarios for anthropogenic climate forcing, namely the different SRES scenarios and RCP scenarios. There is, however, a tendency to focus on the SRES A1B scenario in previous studies and the RCP4.5 and RCP8.5 scenarios, respectively, in the most recent studies. Also, the studies vary considerably in the time periods chosen, both for the present-day and future climate conditions, which can make it difficult to directly compare the magnitude of corresponding projected changes between studies. In particular, some studies focus on projections to the middle of the $21 \mathrm{st}$ century instead of the end of the 21 st century, while some consider projections for both periods. This chapter mostly reports on changes projected at the end of the 21 st century. This is mainly because for most of the forcing scenarios the projected changes are stronger at the end of the century, which means there is a higher probability of the projected regional changes exceeding the range of internal variability at that point. Moreover, the differences between RCP scenarios, in particular between the RCP2.6 and RCP4.5 scenarios, develop during the latter half of the century.

Several factors contribute to the uncertainties in the projected changes, that is, the uncertainty in the climate forcing due to different scenarios, the model uncertainty associated with different climate models, and the uncertainty due to the natural variability of the climate system. By coordinating the simulation of future climate scenarios by different research groups in initiatives such as CMIP3, CMIP5 or CORDEX or in the ENSEMBLES project, the importance of some of these sources of uncertainty can be quantified, ultimately leading to estimates of the likelihood at which certain climatic changes can be expected to occur. With the increase in computer power, climate models have been improved in several respects. In particular, components such as vegetation and marine biogeochemical cycles have been added to coupled climate models leading to the development of earth system models (ESMs) and the horizontal and vertical resolutions of both global and regional 
climate models have been improved, allowing better representation of certain processes in these models. Furthermore, the ongoing development of regionally coupled model systems with an RCM interactively coupled to an ocean model could improve the presentation of climate processes over the North Sea and, hence, the quality of climate simulations for the North Sea region.

Open Access This chapter is distributed under the terms of the Creative Commons Attribution 4.0 International License (http:// creativecommons.org/licenses/by/4.0/), which permits use, duplication, adaptation, distribution and reproduction in any medium or format, as long as you give appropriate credit to the original author(s) and the source, provide a link to the Creative Commons license and indicate if changes were made.

The images or other third party material in this chapter are included in the work's Creative Commons license, unless indicated otherwise in the credit line; if such material is not included in the work's Creative Commons license and the respective action is not permitted by statutory regulation, users will need to obtain permission from the license holder to duplicate, adapt or reproduce the material.

\section{References}

Barnes E, Hartman DL (2010) Influence of eddy-driven jet latitude on North Atlantic jet persistence and blocking frequency in CMIP3 integrations. Geophys Res Lett 37:L23802. doi:10.1029/ 2010GL045700

Barnes E, Polvani L (2013) Response of the midlatitude jets, and of their variability, to increased greenhouse gases in the CMIP5 models. J Clim 26:7117-7135

Barnes E, Slingo J, Woollings T (2012) A methodology for the comparison of blocking climatologies across indices, models and climate scenarios. Clim Dyn 38:2467-2481

Beniston M, Stephenson DB, Christensen OB, Ferro CAT, Frei C, Goyette S, Halsnaes K, Holt T, Jylhä K, Koffi B, Palutikof J, Schöll R, Semmler T, Woth K (2007) Future extreme events in European climate: an exploration of regional climate model projections. Clim Change 81:71-95

Brutel-Vuilmet C, Ménégoz M, Krinner G (2013) An analysis of present and future seasonal Northern Hemisphere land snow cover simulated by CMIP5 coupled climate models. Cryosphere 7:67-80

Cattiaux J, Vautard R, Cassou C, Yiou P, Masson-Delmotte V, Codron F (2010) Winter 2010 in Europe: a cold extreme in a warming climate. Geophys Res Lett 37:L20704. doi:10.1029/ 2010GL044613

Cattiaux J, Douville H, Peings Y (2013) European temperatures in CMIP5: Origins of present-day biases and future uncertainties. Clim Dyn 41:2889-2907

Cattiaux J, Douville H, Schoetter R, Parey S, Yiou P (2015) Projected changes in diurnal and interdiurnal variations of European summer temperatures. Geophys Res Lett 42:899-907

Chang EKM, Guo Y, Xia X (2012) CMIP5 multimodel ensemble projection of storm track change under global warming. GCMs. J Geophys Res 117:D23118. doi:10.1029/2012JD018578

Christensen JH, Hewitson B, Busuioc A, Chen A, Gao X, Held I, Jones R, Kolli RK, Kwon W-T, Laprise R, Magaña Rueda V, Mearns L, Menéndez CG, Räisänen J, Rinke A, Sarr A, Whetton P (2007) Regional climate projections. In: Solomon S, Qin D, Manning M, Chen Z, Marquis M, Averyt KB, Tignor M, Miller HL (eds) Climate Change 2007: The physical science basis.
Contribution of Working Group I to the Fourth Assessment Report of the Intergovernmental Panel on Climate Change. Cambridge University Press

Christensen JH, Krishna Kumar K, Aldrian E, An S-I, Cavalcanti IFA, de Castro M, Dong W, Goswami P, Hall A, Kanyanga JK, Kitoh A, Kossin J, Lau N-C, Renwick J, Stephenson DB, Xie S-P, Zhou T (2013a) Climate phenomena and their relevance for future regional climate change. In: Stocker TF, Qin D, Plattner G-K, Tignor M, Allen SK, Boschung J, Nauels A, Xia Y, Bex V, Midgley PM (eds) Climate Change 2013: The Physical Science Basis. Contribution of Working Group I to the Fifth Assessment Report of the Intergovernmental Panel on Climate Change. Cambridge University Press

Christensen JH, Krishna Kumar K, Aldrian E, An S-I, Cavalcanti IFA, de Castro M, Dong W, Goswami P, Hall A, Kanyanga JK, Kitoh A, Kossin J, Lau N-C, Renwick J, Stephenson DB, Xie S-P, Zhou T (2013b) Climate phenomena and their relevance for future regional climate change; Supplementary Material. In: Stocker TF, Qin D, Plattner GK, Tignor M, Allen SK, Boschung J, Nauels A, Xia Y, Bex V, Midgley PM (eds) Climate Change 2013: The Physical Science Basis. Available from www.climatechange2013.org and www.ipcc.ch

Collins M, Knutti R, Arblaster J, Dufresne J-L, Fichefet T, Friedlingstein P, Gao X, Gutowski WJ, Johns T, Krinner G, Shongwe M, Tebaldi C, Weaver AJ, Wehner M (2013) Long-term climate change: Projections, commitments and irreversibility. In: Stocker TF, Qin D, Plattner GK, Tignor M, Allen SK, Boschung J, Nauels A, Xia Y, Bex V, Midgley PM (eds) Climate Change 2013: The Physical Science Basis. Contribution of Working Group I to the Fifth Assessment Report of the Intergovernmental Panel on Climate Change. Cambridge University Press

Croci-Maspoli M, Schwierz C, Davies H (2007) Atmospheric blocking: space-time links to the NAO and PNA. Clim Dyn 29:713-725

Davini P, Cagnazzo C (2013) On the misinterpretation of the North Atlantic Oscillation in CMIP5 models. Clim Dyn 43:1497-1511

De Winter RC, Sterl A, Ruessink BG (2013) Wind extremes in the North Sea basin under climate change: an ensemble study of 12 CMIP5 GCMs. J Geophys Res 118:1601-1612

Debernard JB, Røed LP (2008) Future wind, wave and storm surge climate in the Northern Seas: a revisit. Tellus 60A:427-438

Deser C, Phillips A, Burdette V, Teng H (2012) Uncertainty in climate change projections: The role of internal variability. Clim Dyn 38:527-546

DMI (2014) Fremtidige klimaændringer I Danmark. Dansk Klimacenter rapport 14-06, DMI, Copenhagen, Denmark

Donat MG, Leckebusch GC, Pinto JG, Ulbrich U (2010) European storminess and associated circulation weather types: future changes deduced from a multi-model ensemble of GCM simulations. Clim Res 42:27-43

Donat MG, Leckebusch GC, Wild S, Ulbrich U (2011) Future changes in European winter storm losses and extreme wind speeds inferred from GCM and RCM multi-model simulations. Nat Hazards Earth Syst Sci 11:1351-1370

Dong B, Sutton RT, Woollings T (2011) Changes of interannual NAO variability in response to greenhouse gases forcing. Clim Dyn 37:1621-1641

Dunn-Sigouin E, Son SW (2013) Northern Hemisphere blocking frequency and duration in the CMIP5 models. J Geophys Res 118:1179-1188

EEA (2012) Climate change, impacts and vulnerability in Europe. European Environment Agency (EEA) Report 12/2012

Feser F, Barcikowska M, Krueger O, Schenk F, Weisse R, Xia L C (2015) Storminess over the North Atlantic and northwestern Europe - A review. Q J Roy Met Soc 141:350-382 
Fischer EM, Schär C (2010) Consistent geographical patterns of changes in high-impact European heatwaves. Nat Geosci 3:398-403

Folland CK, Knight J, Linderholm HW, Fereday D, Ineson S, Hurrell JW (2009) The summer North Atlantic Oscillation: past, present, and future. J Clim 22:1082-1103

Frei C, Schöll R, Fukutome S, Schmidli J, Vidale PL (2006) Future change of precipitation extremes in Europe: Intercomparison of scenarios from regional climate models. J Geophys Res 111: D06105. doi:10.1029/2005JD005965

Frich P, Alexander LV, Della-Marta P, Gleason B, Haylock M, Klein Tank AMG, Peterson T (2002) Observed coherent changes in climatic extremes during the second half of the twentieth century. Clim Res 19:193-212

Gaslikova L, Grabemann I, Groll N (2013) Changes in North Sea storm surge conditions for four transient future climate realizations. Nat Hazards 66:1501-1518

Gillett NP, Fyfe JC (2013) Annular mode changes in the CMIP5 simulations. Geophys Res Lett 40:1189-1193

Giorgi F, Jones C, Asrar GR (2009) Addressing climate information needs at a regional level: the CORDEX framework. Bull World Met Org 58:175-183

Haarsma RJ, Selten F, van Oldenborgh GJ (2013) Anthropogenic changes of the thermal and zonal flow structure over Western Europe and Eastern North Atlantic in CMIP3 and CMIP5 models. Clim Dyn 41:2577-2588

Harvey BJ, Shaffrey LC, Wollings TJ, Zappa G, Hodges KI (2012) How large are projected 21 st century storm track changes? Geophys Res Lett 39:L18707. doi:10.1029/2012GL052873

Henschel F (2013) Projections of insolation changes for solar energy power production. Master Thesis, Swiss Federal Institute for Technology, Zurich

Hewitson B, Janetos AC, Carter TR, Giorgi F, Jones RG, Kwon W-T, Mearns LO, Schipper ELF, van Alst M (2014a) Regional context. In: Barros VR, Field CB, Dokken DJ, Mastrandrea MD, Mach KJ, Bilir TE, Chatterjee K, Ebi KL, Estrada YO, Genova RC, Girma B, Kissel ES, Levy AN, MacCracken S, Mastrandrea PR, White LL (eds) Climate Change 2014: Impacts, Adaptation, and Vulnerability; Part B: Regional Aspects. Contribution of Working Group II to the Fifth Assessment Report of the Intergovernmental Panel on Climate Change. Cambridge University Press

Hewitson B, Janetos AC, Carter TR, Giorgi F, Jones RG, Kwon W-T, Mearns LO, Schipper ELF, van Alst M (2014b) Regional context: Supplementary material. In: Barros VR, Field CB, Dokken DJ, Mastrandrea MD, Mach KJ, Bilir TE, Chatterjee K, Ebi KL, Estrada YO, Genova RC, Girma B, Kissel ES, Levy AN, MacCracken S, Mastrandrea PR, White LL (eds) Climate Change 2014: Impacts, Adaptation, and Vulnerability; Part B: Regional Aspects. Contribution of Working Group II to the Fifth Assessment Report of the Intergovernmental Panel on Climate Change. Available from www.ipcc-wg2.gov/AR5 and www.ipcc.ch

Hodges KI (1999) Adaptive constraints for feature tracking. Mon Wea Rev 127:1362-1373

Hurrell JW, Deser C (2009) North Atlantic climate variability: The role of the North Atlantic Oscillation. J Mar Syst 78:28-41

Hurrell JW, Kushnir Y, Ottersen G, Visbeck M (2003) An overview of the North Atlantic Oscillation. In: Hurrell JW, Kushnir Y, Visbeck M, Ottersen G (eds), The North Atlantic Oscillation: Climate Significance and Environmental Impact. Geophysical Monograph Series, Vol 134, American Geophysical Union, Washington, DC, 1-35, doi:10.1029/134GM01

IPCC (2012) Managing the risks of extreme events and disasters to advance climate change adaptation. In: Field CB, Barros V, Stocker TF, Qin D, Dokken DJ, Ebi KL, Mastrandrea MD, Mach KJ, Plattner G-K, Allen SK, Tignor M, Midgley PM (eds) Special report of the Intergovernmental Panel on Climate Change. Cambridge University Press

IPCC (2013) Annex I: Atlas of global and regional climate projections. In: Stocker TF, Qin D, Plattner GK, Tignor M, Allen SK, Boschung J, Nauels A, Xia Y, Bex V, Midgley PM (eds) Climate Change 2013: The Physical Science Basis. Cambridge University Press

Itoh H (2008) Reconsideration of the true versus apparent Arctic Oscillation. J Clim 21:2047-2062

Jacob D, Petersen J, Eggert B, Alias A, Christensen OB, Bouwer LM, Braun A, Colette A, Déqué M, Georgievski G, Georgopoulou E, Gobiet A, Menut L, Nikulin G, Haensler A, Hempelmann N, Jones C, Keuler K, Kovats S, Kröner N, Kotlarski S, Kriegsmann A, Martin E, van Meijgaard E, Moseley C, Pfeifer S, Preuschmann S, Radermacher C, Radtke K, Rechid D, Rounsevell M, Samuelsson P, Somot S, Soussana J-F, Teichmann C, Valentini R, Vautard R, Weber B, Yiou P (2014) EURO-CORDEX: new high-resolution climate change projections for European impact research. Reg Environ Change 14:563-578

Kendon EJ, Rowell DP, Jones RG, Buonomo E (2008) Robustness of future changes in local precipitation extremes. J Clim 21:4280-4297

Kendon EJ, Roberts NM, Fowler HJ, Roberts MJ, Chan SC, Senior CA (2014) Heavier summer downpours with climate change revealed by weather forecast resolution model. Nature Clim Change 4:570-576

Kharin S, Zwiers FW, Zhang X, Wehner M (2013) Changes in temperature and precipitation extremes in the CMIP5 ensemble. Clim Change 119:345-357

Kjellström E, Bärring L, Jacob D, Jones R, Lenderink G, Schär C (2007) Modelling daily temperature extremes: recent climate and future changes over Europe. Clim Change 81:249-265

Kjellström E, Nikulin G, Hansson U, Strandberg G, Ullerstig A (2011) 21 st century changes in the European climate: uncertainties derived from an ensemble of regional climate model simulations. Tellus 63A: $24-40$

KNMI (2014) KNMI'14 climate scenarios for the Netherlands: a guide for professionals in climate adaptation. KNMI, De Bilt, The Netherlands

Knutti R, Sedláček J (2012) Robustness and uncertainties in the new CMIP5 climate model projections. Nature Clim Change 3:369-373

Koffi B, Koffi E (2008) Heat waves across Europe by the end of the 21st century: multiregional climate simulations. Clim Res 36:153-168

Kovats RS, Valentini R, Bouwer M, Georgopoulou E, Jacob D, Martin E, Rounsevell M, Soussana J-F (2014a) Europe. In: Barros VR, Field CB, Dokken DJ, Mastrandrea MD, Mach KJ, Bilir TE, Chatterjee K, Ebi KL, Estrada YO, Genova RC, Girma B, Kissel ES, Levy AN, MacCracken S, Mastrandrea PR, White LL (eds) Climate Change 2014: Impacts, Adaptation, and Vulnerability; Part B: Regional Aspects. Contribution of Working Group II to the Fifth Assessment Report of the Intergovernmental Panel on Climate Change. Cambridge University Press

Kovats RS, Valentini R, Bouwer M, Georgopoulou E, Jacob D, Martin E, Rounsevell M, Soussana J-F (2014b) Europe; Supplementary material. In: Barros VR, Field CB, Dokken DJ, Mastrandrea MD, Mach KJ, Bilir TE, Chatterjee K, Ebi KL, Estrada YO, Genova RC, Girma B, Kissel ES, Levy AN, MacCracken S, Mastrandrea PR, White LL (eds), Climate Change 2014: Impacts, Adaptation, and Vulnerability; Part B: Regional Aspects. Contribution of Working Group II to the Fifth Assessment Report of the Intergovernmental Panel on Climate Change. Available from www. ipcc-wg2.gov/AR5 and www.ipcc.ch

Lenderink G, van Meijgaard E (2008) Increase in hourly precipitation extremes beyond expectations from temperature changes. Nature Geosci 1:511-514 
Masato G, Hoskins BJ, Wollings T (2013) Winter and summer Northern Hemisphere blocking in CMIP5 models. J Clim 26: 7044-7059

Matsueda M (2011) Predictability of Euro-Russian blocking in summer of 2010. Geophys Res Lett 38:L06801. doi:10.1029/2010GL046557

McInnes KL, Erwin TA, Batholds JM (2011) Global climate model projected changes in $10 \mathrm{~m}$ wind speed and direction due to anthropogenic climate change. Atmos Sci Let 12:325-333

Meehl GA, Covey C, Taylor KE, Delworth T, Stouffer RJ, Latif M, McAvaney B, Mitchell JFB (2007a) The WCRP CMIP3 multi-model dataset: a new era in climate change research. Bull Am Met Soc 88:1383-1394

Meehl GA, Stocker TF, Collins WD, Friedlingstein P, Gaye AT, Gregory JM, Kitoh A, Knutti R, Murphy JM, Noda A, Raper SCB, Watterson IG, WeaverAJ, Zhao Z-C (2007b) Global climate projections. In: Solomon S, Qin D, Manning $\mathrm{M}$, Chen Z, Marquis M, Averyt KB, Tignor M, Miller HL (eds) Climate Change 2007: The Physical Science Basis. Contribution of Working Group I to the Fourth Assessment Report of the Intergovernmental Panel on Climate Change. Cambridge University Press

Metzger MJ, Bunce RGH, Jongman RHG, Mücher CA, Watkins JW (2005) A climatic stratification of the environment of Europe. Glob Ecol Biogeogr 14:549-563

Miller RL, Schmidt GA, Shindell DT (2006) Forced annular changes in the 20th century Intergovernmental Panel on Climate Change Fourth Assessment Report models. J Geophys Res 111:D18101. doi:10.1029/2005JD006323

Mizuta R (2012) Intensification of extratropical cyclones associated with the polar jet change in the CMIP5 global warming projections. Geophys Res Lett 39:L19707. doi:10.1029/2012GL053032

Moss RH, Edmonds JA, Hibbard KA, Manning MR, Rose SK, van Vuuren DP, Carter TR, Emori S, Kainuma M, Kram T, Meehl GA, Mitchell JFB, Nakicenovic N, Riahi K, Smith SJ, Stouffer RJ, Thomson AM, Weyant JP, Wilbanks TJ (2010) The next generation of scenarios for climate change research and assessment. Nature 463:747-756

Nakićenović NJ, Alcamo J, Davis G, de Vries B, Fenhann J, Gaffin S, Gregory K, Grübler A, Jung TY, Kram T, Lebre La Rovere E, Michaelis L, Mori S, Morita T, Pepper W, Pitcher H, Price L, Riahi K, Roehrl A, Rogner H-H, Sankovski A, Schlesinger M, Shukla P, Smith S, Swart R, van Rooijen S, Victor N, Dadi Z (2000) IPCC Special Report on Emission Scenarios. Cambridge University Press

Nikulin G, Kjellström E, Hansson U, Strandberg G, Ullerstig A (2011) Evaluation and future projections of temperature, precipitation and wind extremes over Europe in an ensemble of regional climate simulations. Tellus 63A:41-55

Noble IR, Huq S, Anokhin YA, Carmin J, Goudou D, Lansigan FP, Osman-Elasha B, Villamizar A (2014) Adaptation needs and options. In: Barros VR, Field CB, Dokken DJ, Mastrandrea MD, Mach KJ, Bilir TE, Chatterjee K, Ebi KL, Estrada YO, Genova RC, Girma B, Kissel ES, Levy AN, MacCracken S, Mastrandrea PR, White LL (eds) Climate Change 2014: Impacts, Adaptation, and Vulnerability; Part A: Global and Sectoral Aspects. Contribution of Working Group II to the Fifth Assessment Report of the Intergovernmental Panel on Climate Change. Cambridge University Press

Orlowsky B, Seneviratne SI (2012) Global changes in extremes events: Regional and seasonal dimension. Clim Change 110:669-696

Pryor SC, Nikulin G, Jones C (2012) Influence of spatial resolution on regional model derived wind climates. J Geopsys Res 117: D03117. doi:10.1029/2011JD016822

Räisänen J, Eklund J (2012) 21st century changes in snow climate in Northern Europe: a high-resolution view from ENSEMBLES regional climate models. Clim Dyn 38:2575-2591

Räisänen J, Hansson U, Ullerstig A, Döscher R, Graham LP, Jones C, Meier M, Samuelsson P, Willén U (2003) GCM driven simulations of recent and future climate with the Rossby Centre coupled atmosphere - Baltic Sea regional climate model. SMHI Rep Met Climatol 101

Ruosteenoja K, Räisänen P (2013) Seasonal changes in solar radiation and relative humidity in Europe in response to global warming. J Clim 26:2467-2481

Scaife A, Folland CK, Alexander LV, Moberg A, Knight JR (2008) European climate extremes and the North Atlantic Oscillation. J Clim 21:72-83

Schoetter R, Cattiaux J, Douville H (2014) Changes of western European heat wave characteristics projected by the CMIP5 ensemble. Clim Dyn. doi:10.1007/s00382-014-2434-8

Scoccimarro E, Gualdi S, Bellucci A, Zampieri M, Navarra A (2013) Heavy precipitation events in a warmer climate: Results from CMIP5 models. J Clim 26:7902-7911

Seneviratne SI, Nicholls N, Easterling D, Goodess CM, Kanae S, Kossin J, Luo Y, Marengo J, McInnes K, Rahimi M, Reichstein M, Sorteberg A, Vera C, Zhan X (2012) Changes in climate extremes and their impacts on the natural physical environment. In: Field CB, Barros V, Stocker TF, Qin D, Dokken DJ, Ebi KL, Mastrandrea MD, Mach KJ, Plattner G-K, Allen SK, Tignor M, Midgley PM (eds), Managing the Risks of Extreme Events and Disasters to Advance Climate Change Adaptation. A Special Report of Working Groups I and II of the Intergovernmental Panel on Climate Change (IPCC). Cambridge University Press

Sillmann J, Roeckner E (2008) Indices for extreme events in projections of anthropogenic climate change. Clim Change 86:83-104

Sillmann J, Croci-Maspoli M, Kallache M, Katz RW (2011) Extreme cold winter temperatures in Europe under the influence of North Atlantic atmospheric blocking. J Clim 24:5899-5913

Sillmann J, Kharin S, Zwiers FW, Zhang X, Bronough D (2013) Climate extreme indices in the CMIP5 multimodel ensemble: Part 2. Future climate projections. J Geophys Res 118:2473-2493

Sterl A, van den Brink H, de Vries H, Haarsma R, van Meijgaard E (2009) An ensemble study of extreme surge related water levels in the North Sea in a changing climate. Ocean Sci 5:369-378

Sterl A, Bakker AMR, van den Brink HW, Haarsma R, Stepek A, Wijnant IL, de Winter RC (2015) Large-scale winds in the southern North Sea region: the wind part of the KNMI'14 climate change scenarios. Env Res Lett 10:035004. doi:10.1088/1748-9326/10/3

Taylor K, Stouffer RJ, Meehl GA (2012) An overview of CMIP5 and the experiment design. Bull Am Met Soc 93:485-498

Tebaldi C, Hayhoe K, Arblaster JM, Meehl GA (2006) Going to the extremes. An intercomparison of model-simulated historical and future changes in extreme events. Clim Change 79:185-211

Thompson DWJ, Wallace JM (2000) Annular modes in the extratropical circulation. Part I: Month-to-month variability. J Clim 13: 1000-1016

Trenberth KE, Fasullo JT (2009) Global warming due to increasing absorbed solar radiation. Geophys Res Lett 36:L07706. doi:10. 1019/2009GL037527

Trigo RM, Trigo IF, DaCamara CC, Osborn TJ (2004) Climate impact of the European winter blocking episodes from the NCEP/NCAR Reanalyses. Clim Dyn 23:17-28

Tyrlis E, Hoskins BJ (2008) Aspects of a Northern Hemisphere atmospheric blocking climatology. J Atmos Sci 65:1638-1652

Ulbrich U, Christoph M (1999) A shift of the NAO and increasing storm track activity over Europe due to anthropogenic greenhouse gas forcing. Clim Dyn 15:551-559

Ulbrich U, Pinto JG, Kupfer H, Leckebusch GC, Spangehl T, Reyers M (2008) Changing Northern Hemisphere storm tracks in an ensemble of IPCC climate change simulations. J Clim 21:1669-1679

Ulbrich U, Leckebusch GC, Grieger J, Schuster M, Akperov M, Bardin MY, Feng Y, Gulev S, Inatsu M, Keay K, Kew SF, Liberato MLR, Lionello P, Mokhov II, Neu U, Pinto JG, Raible CC, 
Reale M, Rudeva I, Simmonds I, Tilinina ND, Trigo IF, Ulbrich S, Wang XL, Wernli $\mathrm{H}$ and The IMILAST TEAM (2013) Are greenhouse gas signals of Northern Hemisphere winter extra-tropical cyclone activity dependent on the identification and tracking algorithm? Meteorol Z 22:61-68

Van den Hurk B, van Oldenborgh GJ, Lenderink G, Hazeleger W, Haarsma R, de Vries H (2014) Drivers of mean climate change around the Netherlands derived from CMIP5. Clim Dyn 42:1683-1697

Van der Linden P, Mitchell JFB (2009) ENSEMBLES: Climate change and its impacts: Summary of research and results from the ENSEMBLES project. Met Office Hadley Centre, Exeter

Van Vuuren DP, Edmonds J, Kainuma M, Riahi K, Thomson A, Hibbard K, Hurtt GC, Kram T, Krey V, Lamarque J-F, Masui T, Meinshausen M, Nakicenovic N, Smith SJ, Rose SK (2011) Representative concentration pathways: an overview. Clim Change 109:5-31

Wagner S, Berg P, Schädler G, Kunstmann H (2013) High-resolution regional climate simulations for Germany: Part II - projected climate changes. Clim Dyn 40:415-427

Wiedenmann JM, Lupo AR, Mokhov II, Tikhonova EA (2002) The climatology of blocking anticyclones for the Northern and Southern Hemispheres: Block intensity as a diagnostic. J Clim 15:3459-3473
Wild M, Ohmura A, Cubasch U (1997) GCM-simulated surface energy fluxes in climate change experiments. J Clim 10:3093-3110

Winterfeldt J, Weisse R (2009) Assessment of value added for surface marine wind speed obtained from two regional climate models. Mon Wea Rev 137:2955-2965

Woollings T (2010) Dynamical influences on European climate: An uncertain future. Phil Trans Roy Soc 368A:3733-3756

Woollings T, Blackburn M (2012) The North Atlantic jet stream under climate change and its relation to the NAO and EA patterns. J Clim 25:886-902

Zappa G, Sheffrey LC, Hodges KI, Sansom PG, Stephenson DB (2013) A multimodel assessment of future projections of North Atlantic and European extratropical cyclones in the CMIP5 climate models. J Clim 26:5846-5862

Zhang X, Alexander L, Hegerl GC, Jones P, Klein Tank A, Peterson TC, Trewin B, Zwiers FW (2011) Indices for monitoring changes in extremes based on daily temperature and precipitation data. WIREs Clim Change 2:851-870

Zhou L, Dickinson RE, Dirmeyer P, Dai A, Min SK (2009) Spatiotemporal patterns of changes in maximum and minimum temperatures in multi-model simulations. Geophys Res Lett 36: L02702. doi:10.1019/2008GL036141 